\title{
Emergency Response Measures to Alleviate a Severe Haze Pollution Event in Northern China during December 2015: Assessment of Effectiveness
}

\author{
Yaping Ma1, Tzung-May Fu²,3*, Heng Tian', Jian $\mathrm{Gao}^{4}$, Min $\mathrm{Hu}^{5}$, Jianping Guo ${ }^{6}$, \\ Yangmei Zhang ${ }^{7}$, Yele Sun ${ }^{8}$, Lijuan Zhang', Xin Yang ${ }^{2,3}$, Xiaofei Wang,10 \\ ${ }^{1}$ Department of Atmospheric and Oceanic Sciences, Peking University, Beijing 100871, China \\ ${ }^{2}$ State Environmental Protection Key Laboratory of Integrated Surface Water-Groundwater Pollution Control, School of \\ Environmental Science and Engineering, Southern University of Science and Technology, Guangdong 518055, China \\ ${ }^{3}$ Shenzhen Institute of Sustainable Development, Southern University of Science and Technology, Guangdong 518055, \\ China \\ ${ }^{4}$ State Key Laboratory of Environmental Criteria and Risk Assessment, Chinese Research Academy of Environmental \\ Science, Beijing 100012, China \\ ${ }^{5}$ State Key Joint Laboratory of Environmental Simulation and Pollution Control, College of Environmental Sciences and \\ Engineering, Peking University, Beijing 100871, China \\ ${ }^{6}$ State Key Laboratory of Severe Weather, Chinese Academy of Meteorological Sciences, Beijing 100081, China \\ ${ }^{7}$ Key Laboratory of Atmospheric Chemistry, Chinese Academy of Meteorological Sciences, Beijing 100081, China \\ ${ }^{8}$ State Key Laboratory of Atmospheric Boundary Layer Physics and Atmospheric Chemistry, Institute of Atmospheric \\ Physics, Chinese Academy of Sciences, Beijing 100191, China \\ ${ }^{9}$ Shanghai Key Laboratory of Atmospheric Particle Pollution and Prevention, Department of Environmental Science and \\ Engineering, Fudan University, Shanghai 200433, China \\ ${ }^{10}$ Shanghai Institute of Pollution Control and Ecological Security, Shanghai 200092, China
}

\begin{abstract}
Using the WRF-Chem model, we simulated the surface $\mathrm{PM}_{2.5}$ concentrations on the North China Plain (NCP) during a severe winter haze episode (December 6-10, 2015) with the goal of assessing the effectiveness of the implemented emergency response measures (ERMs) in alleviating the pollution. We estimated that the ERMs decreased the anthropogenic pollutant emissions, with the exception of $\mathrm{NH}_{3}$, by 8-48\% during this event. Inputting these reduced emission estimates, our simulations reproduced the observed $\mathrm{PM}_{2.5}$ concentrations and compositions. Stagnant regional meteorological conditions increased the lifetime of the $\mathrm{PM}_{2.5}$ in the NCP boundary layer from 1 day during the clean period to 5 days during the haze episode. Additionally, local emissions accounted for approximately only $20 \%$ of the surface $\mathrm{PM}_{2.5}$ in Beijing but more than $62 \%$ over the rest of the NCP. We found that the ERMs achieved a modest reduction in the mean surface $\mathrm{PM}_{2.5}$ concentrations during the event, decreasing them by $7 \%$ and $4 \%$ in Beijing and across the rest of the NCP, respectively. The limited effect was due to the duration of the ERMs being much shorter than the lifetime of the $\mathrm{PM}_{2.5}$, which prevented the concentrations of the latter from fully reflecting the reduction in emissions. We conclude that anthropogenic emissions on the NCP during severe winter haze episodes must be reduced by a much larger percentage to substantially abate the $\mathrm{PM}_{2.5}$ concentrations.
\end{abstract}

Keywords: $\mathrm{PM}_{2.5}$; Severe haze; Emission reduction; Northern China; WRF-Chem.

\section{INTRODUCTION}

The region of the North China Plain (hereafter referred to as the "NCP", as shown in Fig. 1(b)), including the BeijingTianjin-Hebei (BTH) area and the surrounding provinces of

\footnotetext{
* Corresponding author.

E-mail address: fuzm@sustech.edu.cn
}

Shandong and Henan, has been experiencing severe winter haze pollution events of hourly $\mathrm{PM}_{2.5}$ concentrations exceeding $150 \mathrm{\mu g} \mathrm{m}^{-3}$ in recent years (Dang and Liao, 2019), which pose threats to public health (e.g., Chen et al., 2013). These severe wintertime $\mathrm{PM}_{2.5}$ pollution events are typically associated with the accumulation of $\mathrm{PM}_{2.5}$ and its precursors under stagnant weather conditions. Such stagnant conditions prevent the horizontal and vertical ventilation of pollutants and are often associated with high humidity near the surface, which in turn promotes secondary $\mathrm{PM}_{2.5}$ production (Jeong 
and Park, 2013; Zhang et al., 2014; Tie et al., 2017; Leung et al., 2018; Zhang et al., 2018). The NCP is blocked by mountains to the north and to the west, which also contributes to the accumulation of $\mathrm{PM}_{2.5}$ and its precursors under calm or southerly wind conditions (Wang et al., 2010; Wang et al., 2019). These severe winter haze events are terminated by the passage of a cold front, which ventilates the region with strong wind and clean air from the north (Wang et al., 2017).

In September 2013, the State Council of China promulgated the Air Pollution Prevention and Control Action Plan (hereafter referred to as the "Action Plan"; State Council of the People's Republic of China, 2013), which outlined the policies on reducing nationwide anthropogenic emissions, as well as set specific improvement targets for the annual mean $\mathrm{PM}_{2.5}$ concentrations for key areas, including Beijing and the BTH area, by 2017. Between 2013 and 2018, the annual mean $\mathrm{PM}_{2.5}$ concentrations for most Chinese cities have dropped (Ministry of Environmental Protection of the People's Republic of China, 2014, 2015, 2016, 2017; Ministry of Ecology and Environment of the People's Republic of China, 2018, 2019), likely in part due to the nationwide emission reduction. The annual mean $\mathrm{PM}_{2.5}$ concentrations in Beijing and in BTH in 2017 were reduced to $58 \mu \mathrm{g} \mathrm{m}^{-3}$ and $64 \mu \mathrm{g} \mathrm{m}^{-3}$ (Ministry of Ecology and Environment of the People's Republic of China, 2018), respectively, both meeting the improvement targets set by the Action Plan. However, analyses of observations showed that the frequency and intensity of wintertime haze events over the NCP have not shown significant decline since 2013 (Zhang et al., 2018; Dang and Liao, 2019).

To alleviate the severe haze events, the Action Plan mandated that local environmental protection bureaus and meteorological bureaus join forces to establish a protocol for the issuance and execution of emergency response measures (ERMs). For the NCP area, the Monitoring and Warning Scheme for Heavy Pollution Weather in Beijing, Tianjin, Hebei, and Its Surrounding Areas was issued in September 2013 to combat severe haze events (Ministry of Environmental Protection of the People's Republic of China, 2013). This scheme categorized the severity of local air pollution into four levels, based on the duration for which the forecasted hourly air quality index (AQI) exceeds 200 (equivalent to hourly $\mathrm{PM}_{2.5}$ exceeding $150 \mu \mathrm{g} \mathrm{m}^{-3}$ ). When such severe $\mathrm{PM}_{2.5}$ pollution events are forecasted, the provincial and municipal governments are to issue emergency alerts at least 24 hours in advance. Each alert level corresponds to a set of ERMs to reduce anthropogenic pollutant emissions (Table S1):

(1) Blue alert: hourly $\mathrm{PM}_{2.5}$ concentrations are forecasted to exceed $150 \mu \mathrm{g} \mathrm{m}^{-3}$ and to persist for 24 hours.

(2) Yellow alert: hourly $\mathrm{PM}_{2.5}$ concentrations are forecasted to exceed $150 \mu \mathrm{g} \mathrm{m}^{-3}$ and to persist for 48 hours.

(3) Orange alert: hourly $\mathrm{PM}_{2.5}$ concentrations are forecasted to exceed $150 \mu \mathrm{g} \mathrm{m}^{-3}$ and to persist for 72 hours.

(4) Red alert: hourly $\mathrm{PM}_{2.5}$ concentrations are forecasted to exceed $150 \mu \mathrm{g} \mathrm{m}^{-3}$ and to persist for more than 72 hours.

On December 5, 2015, at 11:00 UTC (19:00 local time), the Beijing municipal government issued an orange alert for severe haze pollution, with the corresponding ERMs to be initiated at 16:00 UTC on December 6. The city of Tianjin and most cities in Hebei, Henan, and Shandong Provinces issued various alert levels for severe haze pollution, with corresponding ERMs to be initiated between 16:00 UTC on December 5 and 16:00 UTC on December 7 (Fig. S1). The city of Beijing later upgraded its alert level to the first-ever red alert at 10:00 UTC on December 7, with the corresponding stricter ERMs to be initiated at 23:00 UTC on December 7. Tianjin and Hebei also updated their alert levels, with stricter ERMs to be initiated between 23:00 UTC on December 7 and 16:00 UTC on December 8 (Fig. S1). The issuance of the red alert led to the enforcement of stricter emission reduction measures, including the emergency shutdown of more industrial plants and further restrictions of vehicle numbers on the road (Table S1). This was the first time the Chinese government evoked restrictive ERMs based on air quality forecasts to mitigate severe pollution events. Though the alert levels issued in the NCP varied, the ERM-initiation times in $>90 \%$ of the cities were within 16 hours of the ERM-initiation times in Beijing. We referred to the emission reductions in two stages according to the ERMinitiation times in Beijing (Fig. S1). Stage I was between 16:00 UTC on December 6 and 23:00 UTC on December 7, during which the orange alert was in effect in Beijing and Henan, and the yellow alert was in effect in Tianjin, Hebei, and Shandong. Stage II was between 23:00 UTC on December 7 and 04:00 UTC on December 10, during which the red alert was in effect in Beijing, the orange alert was in effect in Tianjin, Hebei, and Henan, and the yellow alert was in effect in Shandong.

The Chinese government had previously administered pre-planned emission controls before and during several important events that took place in Beijing to improve the local air quality (Table S2). Such events included the SinoAfrican summit in November 2006 (Wang et al., 2007; Cheng et al., 2008), the Beijing Olympic Games in August 2008 (Wang et al., 2010; Schleicher et al., 2012), the AsiaPacific Economic Cooperation (APEC) summit in November 2014 (Li et al., 2015; Guo et al., 2016a; Zhang et al., 2016; Liu et al., 2017), and the Chinese Military Parade in September 2015 (Wang et al., 2017; Huang et al., 2018). The emission control actions taken included temporary closures of factories, restrictions on the numbers and types of on-road motor vehicles, and restrictions on construction. The control actions were enforced in Beijing and its surrounding cities and provinces, including Tianjin, Hebei, Shandong, Shanxi, Henan and the Inner Mongolia Autonomous Region. The resulting reductions in primary pollutant emissions were estimated to be $40-70 \%$ in Beijing and $30-70 \%$ in the surrounding cities and provinces (Wang et al., 2007; Liu et al., 2015). Previous studies estimated that these emission control actions may have led to dramatic declines in $\mathrm{SO}_{2}$, $\mathrm{NO}_{x}$, and $\mathrm{PM}_{2.5}$ concentrations in Beijing and its surrounding areas by 30-70\% during the APEC summit (Liu et al., 2015; Zhang et al., 2016) and by 50\% during the Chinese Military Parade (Wang et al., 2017). However, these pre-planned emission controls were enforced over much larger spatial areas, often lasted for weeks, and were in most cases stricter than the ERMs implemented from December 6 to 10, 2015. More importantly, those previous events all took place either 
in summer or in fall, when the regional meteorological conditions were more favorable to the dispersion or removal of pollutants, aiding the efficacy of the emission control actions (Zhang et al., 2016; Huang et al., 2018).

In comparison, the short-term ERMs administered during severe wintertime haze events were likely to be less effective, because the stagnant meteorological conditions impeded pollutant dispersion, the controls were less strict, and the enforcement was over a smaller domain and for a shorter period of time. A few studies have attempted to quantify the impacts of emission reduction measures on the $\mathrm{PM}_{2.5}$ concentrations in the NCP during haze events or haze seasons, but these studies did not distinguish the impacts of China-wide long-term emission controls and the short-term ERMs. Wu et al. (2017) simulated the effects of a hypothetical $30 \%$ reduction of monthly anthropogenic emissions in the BTH area during the entire January 2012 and found a 20\% decline in the local monthly mean $\mathrm{PM}_{2.5}$ concentration. Liu et al. (2017) estimated that the overall reduction of anthropogenic emissions since the year 2014 over the NCP led to a $9 \%$ decline in the monthly mean $\mathrm{PM}_{2.5}$ concentration over the NCP in December 2015 relative to December 2014. Chen et al. (2019) simulated the $\mathrm{PM}_{2.5}$ concentrations in Beijing during four seasonal haze episodes (November 2016 versus November 2017, and March 2013 versus March 2018). They estimated that the overall reduction of anthropogenic emissions since 2013 led to $33 \%$ and $16 \%$ decreases of the simulated monthly mean $\mathrm{PM}_{2.5}$ concentrations in Beijing in November 2017 and March 2018, relative to November 2016 and March 2013, respectively. However, it is likely that the decline in monthly mean $\mathrm{PM}_{2.5}$ concentrations inferred by these three previous studies were mainly due to the long-term emission control in China and not specifically to the ERMs. Wang et al. (2020) hypothetically simulated the effects of emergency emission reduction on $\mathrm{PM}_{2.5}$ concentrations during a 5-day severe haze event over the Yangtze River Delta area. They found that a short-term, 20$90 \%$ reduction of power, transportation, and industry emissions, comparable to the strictest ERMs, would only lead to a $16 \%$ reduction in $\mathrm{PM}_{2.5}$ concentration. To the best of our knowledge, the effectiveness of the ERMs administered over the NCP area during severe haze events has not been explicitly evaluated.

It is also important to quantitatively assess the relative contributions of local and regional pollutant emissions to the local $\mathrm{PM}_{2.5}$ concentrations during severe haze events, in order to help municipal policy-makers formulate effective emergency responses. Zhang et al. (2015) previously found that $50 \%$ of the $\mathrm{PM}_{2.5}$ in Beijing during January 2013 was due to emissions within Beijing, while the remaining 50\% were due to emissions from nearby provinces in northern China. However, in view of the large emissions reductions in all provinces and cities in northern China since 2013, that fraction may have changed significantly and should be reevaluated.

In this study, we explicitly simulated surface $\mathrm{PM}_{2.5}$ concentrations over the NCP from December 2 to 10, 2015, both with and without the emission reductions associated with the ERMs, to assess the effectiveness of the ERMs on alleviating severe haze pollution. We also quantified the relative contributions of local and regional emissions to $\mathrm{PM}_{2.5}$ concentrations in Beijing and over the rest of the NCP during this severe haze event. Finally, we analytically interpret the effectiveness/ineffectiveness of the ERMs during this haze event, in order to better inform future emergency response strategies.

\section{MODEL AND DATA}

\section{WRF-Chem Model}

We used the WRF-Chem regional air quality model version 3.6.1 (Grell et al., 2005) to simulate surface $\mathrm{PM}_{2.5}$ over the NCP from November 26 to December 10, 2015. The first 6 days spun up the model; results for December 210, 2015, were analyzed. Fig. 1 shows the two nested domains in our simulations with horizontal resolutions of $81 \mathrm{~km}$ and $27 \mathrm{~km}$, respectively. The $27-\mathrm{km}$ horizontal resolution in the inner domain was consistent with the $0.25^{\circ}$ resolution of the anthropogenic emission inventory (Section 2.2). The model consisted of 30 vertical layers extending from the surface to $50 \mathrm{hPa}$, with 7 layers in the bottom $1 \mathrm{~km}$. Meteorological initial and boundary conditions into WRFChem were from the NCEP FNL Operational Global Analysis data (Kalnay et al., 1996) and updated every 6 hours. Chemical initial and boundary conditions were from a MOZART global model simulation (Emmons et al., 2010), except we reduced the boundary conditions of dust concentrations by $50 \%$ following Georgiou et al. (2018). We nudged the temperature, humidity, and wind in WRF-Chem with hourly surface meteorological measurements and twice-daily rawinsonde profiles over China (Guo et al., 2016b) using four-dimensional data assimilation to reduce errors in the simulated meteorology (Gilliam et al., 2012).

Gas-phase chemistry in WRF-Chem was simulated using the SAPRC-99 mechanism (Carter, 2000), updated to include the photochemistry of dicarbonyls (Li et al., 2013). $\mathrm{PM}_{2.5}$ in our model included primary elemental carbon aerosol (EC), primary organic aerosol (POA), secondary inorganic aerosol (sulfate, nitrate, and ammonium), secondary organic aerosol (SOA), anthropogenic and natural dust, and sea salt. Aerosol microphysics and gas-particle partitioning were simulated using the MOSAIC module (Zaveri et al., 2008). SOA productions from anthropogenic and biogenic volatile organic precursors were simulated with the VBS module (Lane et al., 2008). We also included the aqueous uptake of glyoxal and methylglyoxal as a source of SOA (Fu et al., 2008, 2009; Li et al., 2013). We optimized the deposition velocity of fog droplets in WRF-Chem to $0.3 \mathrm{~cm} \mathrm{~s}^{-1}$ to be consistent with the observed fog droplet radius of 2-3 $\mu \mathrm{m}$ over the NCP (Zhang et al., 2014; Seinfeld and Pandis, 2006).

A number of studies have proposed fast, heterogeneous sulfate production pathways, potentially catalyzed by nitrogen dioxide or metal ions, during severe haze events over the NCP (He et al., 2014; Cheng et al., 2016; Wang et al., 2016; Liu et al., 2017; Zhao et al., 2017; Hung et al., 2018; Shao et al., 2019). The exact pathway responsible for the high sulfate concentrations during the severe wintertime haze events in the NCP is still uncertain. Nevertheless, we added 


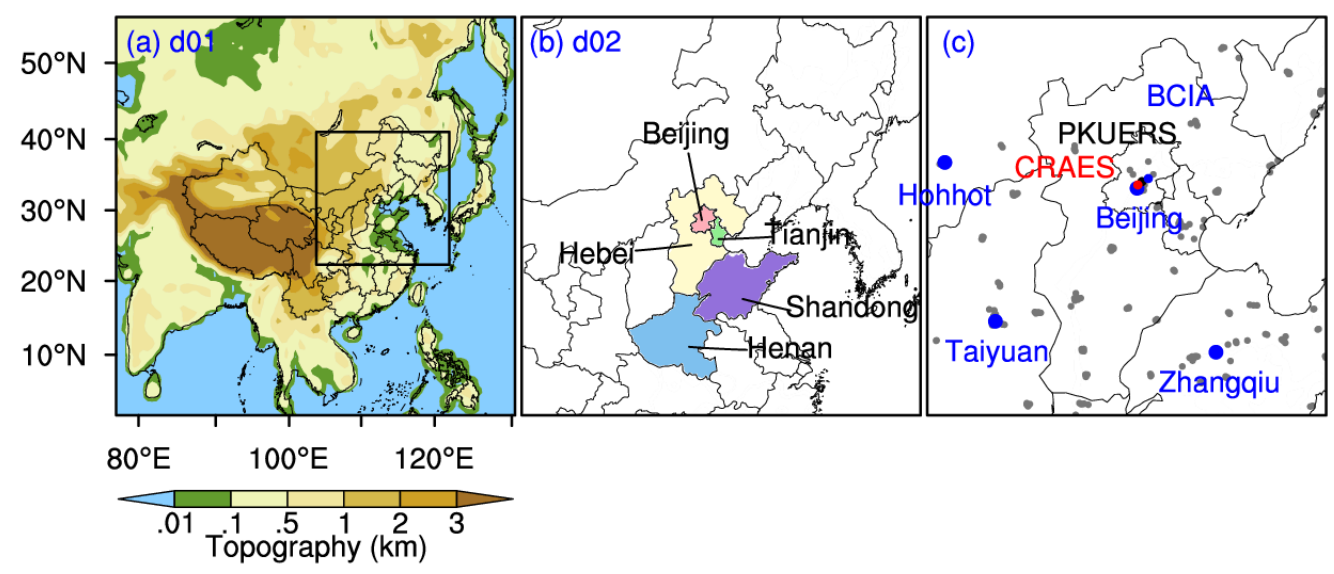

Fig. 1. (a) The two nested domains used in our WRF-Chem simulations. The outer domain (d01) is shown with the topography (filled contours). (b) The inner domain (d02) is color-shaded to represent the NCP areas (Beijing, Tianjin, Hebei, Henan, and Shandong), which implemented emission reduction measures during December 6 to 10, 2015. (c) The spatial distribution of meteorology and $\mathrm{PM}_{2.5}$ measurement sites used in this study. The blue dots represent the meteorological sites. The black and red dots indicate the PKUERS and CRAES sites with $\mathrm{PM}_{2.5}$ concentration and composition measurements. The grey dots indicate other surface sites of $\mathrm{PM}_{2.5}$ concentration measurements.

in our WRF-Chem simulation the sulfate production via the heterogeneous uptake of $\mathrm{SO}_{2}$ by aqueous aerosols as parameterized by Wang et al. (2016), on the account that this parameterization led to a good simulation of the observed sulfate concentration during our study period (Section 3.1.2). The production rate of sulfate by the heterogeneous oxidation of $\mathrm{SO}_{2}$ on particles was parameterized as:

$\left.\frac{d\left[\mathrm{SO}_{4}^{2-}\right]}{d t}\right|_{\text {hetero }}=\frac{1}{4} \gamma \bar{v} S_{c}\left[\mathrm{SO}_{2}\right]$

$d\left[\mathrm{SO}_{4}{ }^{2-}\right] /\left.d t\right|_{\text {hetero }}$ was the rate of heterogeneous production of sulfate (ppmv s $\left.{ }^{-1}\right) ; \gamma$ was the effective uptake coefficient of $\mathrm{SO}_{2}$ on aqueous aerosol surfaces; $\bar{v}$ was the mean molecular speed of $\mathrm{SO}_{2}\left(\mathrm{~m} \mathrm{~s}^{-1}\right) ; S_{c}$ was the aerosol surface area density $\left(\mathrm{m}^{2} \mathrm{~m}^{-3}\right.$ dry air); [ $\left.\mathrm{SO}_{2}\right]$ was the gaseous $\mathrm{SO}_{2}$ concentrations (ppmv). We used the values $\gamma=1.6 \times 10^{-5}$ for relative humidity $(\mathrm{RH})<41 \%, \gamma=2.1 \times 10^{-5}$ for $\mathrm{RH}$ between $41 \%$ and $56 \%$, and $\gamma=4.5 \times 10^{-5}$ for $\mathrm{RH}>56 \%$, as observationally constrained by Wang et al. (2016).

\section{Emissions}

Chinese monthly anthropogenic emissions of $\mathrm{PM}_{2.5}$ precursors and primary $\mathrm{PM}_{2.5}$ were from the Multi-resolution Emission Inventory for China (MEIC), developed by Tsinghua University (http://meicmodel.org; Li et al., 2017) for the year 2016 at a horizontal resolution of $0.25^{\circ}$. Anthropogenic source activities included power generation, industries, residential activities, on-road transportation, and agriculture. Activity levels were based on provincial statistics for the year 2016. Anthropogenic emissions for the rest of Asia were from the MIX inventory (Li et al., 2017), developed for the year 2010 at a horizontal resolution of $0.25^{\circ}$. We applied diurnal variations to transportation and residential emissions ( $\mathrm{Li}$ et al., 2013). Emissions from power generation were injected into the second vertical layer in the model, approximately $100 \mathrm{~m}$ above the surface.

Daily biomass burning emissions were taken from the Fire INventory from NCAR (FINN; version 1.5; Wiedinmyer et al., 2011) for the study period. Dust emissions were calculated online using the Goddard Global Ozone Chemistry Aerosol Radiation and Transport (GOCART) dust scheme (Ginoux et al., 2001) with the Air Force Weather Agency modifications (GOCART-AFWA; LeGrand et al., 2019). Biogenic emissions were calculated online using the MEGAN module (version 2.04; Guenther et al., 2006).

\section{Emission Reductions Associated with ERMs}

We systematically surveyed the government announcements and news reports released from December 6 to 10, 2015, to determine the issued alert levels, the ERMs administered for each of the cities and provinces in the NCP, and the start/end times of ERM implementation (Table S1 and Fig. S1). The emission reductions associated with the ERMs for the industrial, residential, and transportation sectors were estimated based on the guidelines and activity advisories in the Emergency Plan for Heavy Air Pollution issued by each city or province. Table 1 summarized the percentages of sectoral emission reductions as a result of the ERMs for Beijing, Tianjin, Hebei, Henan, and Shandong, respectively, from December 6 to 10, 2015.

Table 2 shows the calculated short-term reductions in anthropogenic pollutant emissions for each of the cities and provinces in the NCP from December 6 to 10, 2015, using the percentages in Table 1. As shown in Table 2, anthropogenic emissions were reduced most dramatically in Beijing, due to the enforcement of the strictest ERMs. Anthropogenic emissions of VOCs, $\mathrm{SO}_{2}$, and $\mathrm{NO}_{x}$ in Beijing during Stage II were reduced by $48 \%, 34 \%$, and $38 \%$, respectively. Anthropogenic emissions of primary $\mathrm{PM}_{2.5}$ constituents, such as EC, POA, and anthropogenic dust, were also significantly reduced in Beijing due to enforced restrictions on residential emissions and constructions. Emissions of 
Table 1. Percent reductions in sectorial anthropogenic emissions associated with the various alert levels issued by the cities and provinces in the NCP during December 6 to 10, 2015.

\begin{tabular}{|c|c|c|c|c|}
\hline \multirow{2}{*}{ City/Province } & \multirow{2}{*}{ Sector } & \multicolumn{3}{|c|}{ Percentage of emission reduction } \\
\hline & & Yellow alert & Orange alert & Red alert \\
\hline \multirow[t]{4}{*}{ Beijing } & Power generation & $-{ }^{a}$ & $0^{\mathrm{b}}$ & 0 \\
\hline & Industry & - & $-15 \%$ & $-50 \%$ \\
\hline & Residential activities & - & $-10 \%$ & $-30 \%$ \\
\hline & Transportation & - & $-30 \%$ & $-42 \%$ \\
\hline \multirow[t]{4}{*}{ Tianjin } & Power generation & 0 & 0 & - \\
\hline & Industry & $-20 \%$ & $-30 \%$ & - \\
\hline & Residential activities & $-10 \%$ & $-10 \%$ & - \\
\hline & Transportation & 0 & 0 & - \\
\hline \multirow[t]{4}{*}{ Hebei } & Power generation & 0 & 0 & - \\
\hline & Industry & $-15 \%$ & $-30 \%$ & - \\
\hline & Residential activities & $-10 \%$ & $-10 \%$ & - \\
\hline & Transportation & $-20 \%$ & $-20 \%$ & - \\
\hline \multirow[t]{4}{*}{ Henan } & Power generation & - & 0 & - \\
\hline & Industry & - & $-30 \%$ & - \\
\hline & Residential activities & - & $-10 \%$ & - \\
\hline & Transportation & - & $-20 \%$ & - \\
\hline \multirow[t]{4}{*}{ Shandong } & Power generation & 0 & - & - \\
\hline & Industry & $-10 \%$ & - & - \\
\hline & Residential activities & $-10 \%$ & - & - \\
\hline & Transportation & $-10 \%$ & - & - \\
\hline
\end{tabular}

a '-' indicates that the alert level was not issued.

$\mathrm{b}$ ' 0 ' indicates that no emission reductions associated with the sector at the issued alert level.

Table 2. Pollutant emissions from the cities and provinces in the NCP and the associated percent reductions during Stages $\mathrm{I}^{\mathrm{a}}$ and $\mathrm{II}^{\mathrm{b}}$.

\begin{tabular}{|c|c|c|c|c|c|c|c|c|c|}
\hline & $\begin{array}{l}\text { Base emissions/ } \\
\text { alert levels }\end{array}$ & $\mathrm{EC}$ & $\begin{array}{l}\text { Primary } \\
\mathrm{OC}^{\mathrm{c}}\end{array}$ & $\begin{array}{l}\text { Other } \\
\text { primary } \\
\mathrm{PM}_{2.5}\end{array}$ & VOCs & $\mathrm{SO}_{2}$ & $\mathrm{NO}_{\mathrm{x}}$ & $\mathrm{NH}_{3}$ & $\mathrm{CO}$ \\
\hline \multirow[t]{3}{*}{ Beijing } & Base (Mg) & 23 & 62 & 71 & 1299 & 125 & 699 & 61 & 4362 \\
\hline & Stage I reduction & $-13 \%$ & $-11 \%$ & $-12 \%$ & $-15 \%$ & $-12 \%$ & $-18 \%$ & $-4 \%$ & $-14 \%$ \\
\hline & Stage II reduction & $-34 \%$ & $-31 \%$ & $-35 \%$ & $-48 \%$ & $-34 \%$ & $-38 \%$ & $-9 \%$ & $-34 \%$ \\
\hline \multirow{3}{*}{ Tianjin } & Base (Mg) & 49 & 82 & 118 & 1818 & 503 & 1181 & 96 & 6349 \\
\hline & Stage I reduction & $-11 \%$ & $-11 \%$ & $-13 \%$ & $-18 \%$ & $-17 \%$ & $-14 \%$ & $-1 \%$ & $-12 \%$ \\
\hline & Stage II reduction & $-14 \%$ & $-12 \%$ & $-16 \%$ & $-27 \%$ & $-24 \%$ & $-21 \%$ & $-2 \%$ & $-16 \%$ \\
\hline \multirow[t]{3}{*}{ Hebei } & Base (Mg) & 387 & 686 & 697 & 4929 & 2823 & 4963 & 1212 & 45560 \\
\hline & Stage I reduction & $-12 \%$ & $-11 \%$ & $-12 \%$ & $-14 \%$ & $-13 \%$ & $-14 \%$ & $-1 \%$ & $-12 \%$ \\
\hline & Stage II reduction & $-16 \%$ & $-13 \%$ & $-18 \%$ & $-24 \%$ & $-22 \%$ & $-23 \%$ & $-2 \%$ & $-18 \%$ \\
\hline \multirow[t]{2}{*}{ Henan } & Base $(\mathrm{Mg})$ & 330 & 599 & 691 & 5110 & 1918 & 3920 & 2176 & 32374 \\
\hline & Stages I and II reduction & $-17 \%$ & $-13 \%$ & $-19 \%$ & $-24 \%$ & $-20 \%$ & $-20 \%$ & $-2 \%$ & $-17 \%$ \\
\hline \multirow[t]{2}{*}{ Shandong } & Base $(\mathrm{Mg})$ & 413 & 804 & 1127 & 8357 & 42218 & 6588 & 1689 & 45260 \\
\hline & Stages I and II reduction & $-10 \%$ & $-10 \%$ & $-9 \%$ & $-10 \%$ & $-8 \%$ & $-8 \%$ & $-1 \%$ & $-10 \%$ \\
\hline
\end{tabular}

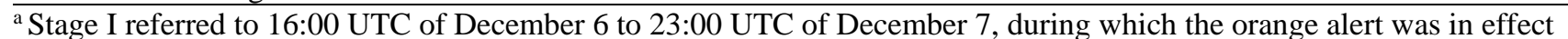
in Beijing.

${ }^{\mathrm{b}}$ Stage II referred to 23:00 UTC of December 7 to 04:00 UTC of December 10, during which the red alert was in effect in Beijing.

${ }^{\mathrm{c}}$ Input into WRF-Chem as organic carbon.

most anthropogenic pollutants in Tianjin, Hebei, and Henan were significantly reduced by $11-27 \%$, but the emission reductions in Shandong were generally less than $10 \%$. Anthropogenic $\mathrm{NH}_{3}$ emissions were reduced by only 1-9\% across the NCP, as $\mathrm{NH}_{3}$ was mostly emitted by agricultural activities and minimally affected by the ERMs.
Several previous studies have assessed the emission reductions associated with pre-planned emission control actions in Beijing using inverse modeling of observations. For example, satellite-based $\mathrm{NO}_{2}$ observations indicated that the prohibition of heavy-duty diesel vehicles and the $50 \%$ reduction of vehicle numbers on city roads throughout the 
NCP reduced the $\mathrm{NO}_{x}$ emission by $30-47 \%$ in the NCP during the Beijing Olympic Games (Wang et al., 2010), the APEC summit (Huang et al., 2015), and the Chinese Military Parade (Zhang et al., 2017). Similarly, satellite-based $\mathrm{SO}_{2}$ observations indicated that the reduction of industrial production, the temporary closure of power plants, and the prohibition of heavy-duty diesel vehicles on roads reduced the $\mathrm{SO}_{2}$ emissions in Beijing by 34-46\% during the APEC summit and the Chinese Military Parade (Wang et al., 2017; Zhang et al., 2017). These control actions were similar to the ERMs implemented in Beijing during our haze event, and we also estimated a $38 \%$ reduction of $\mathrm{NO}_{x}$ emissions and $34 \%$ reduction of $\mathrm{SO}_{2}$ emission in Beijing.

\section{Measurements of Meteorological Conditions and Air Pollutants}

Hourly air pollutant concentrations were measured at 239 surface sites across the NCP, operated by the China National Environmental Monitoring Centre (http://www.cnemc.cn). At each site, $\mathrm{PM}_{2.5}$ mass concentrations were measured using either the micro-oscillating balance method or the $\beta$ absorption method (Ministry of Environmental Protection of the People's Republic of China, 2012).

Hourly $\mathrm{PM}_{2.5}$ concentrations were also continuously measured at the Chinese Research Academy of Environmental Sciences in Beijing (CRAES; $40.04^{\circ} \mathrm{N}, 116.42^{\circ} \mathrm{E}$ ) from December 2 to 10,2015 . The CRAES site is located $8 \mathrm{~m}$ above ground in a mixed residential/commercial area with no strong point sources nearby (Gao et al., 2016). Approximately $10 \mathrm{~km}$ away, daily 24-h filter samples of $\mathrm{PM}_{2.5}$ were collected at the Peking University Urban Atmosphere Environment Monitoring Station (PKUERS; $\left.39.99^{\circ} \mathrm{N}, 116.31^{\circ} \mathrm{E}\right)$, located on the roof of an academic building (Tang et al., 2018). Teflon filter samples were analyzed for inorganic ions using the Dionex ICS-2500 and ICS-2000. Quartz filter samples were analyzed for EC and organic carbon (OC) using a thermal-optical instrument (Model-4; Sunset Laboratory) following the NIOSH protocol (Tang et al., 2018).

Meteorological observations used to validate our simulations included hourly measurements at surface weather sites across China, as well as twice-daily rawinsondes in Beijing $\left(39.93^{\circ} \mathrm{N}, \quad 116.28^{\circ} \mathrm{E}\right), \quad$ Zhangqiu $\left(36.70^{\circ} \mathrm{N}, \quad 117.55^{\circ} \mathrm{E}\right.$; Shandong Province), Taiyuan $\left(37.78^{\circ} \mathrm{N}, 112.55^{\circ} \mathrm{E}\right.$; Shanxi Province), and Hohhot $\left(40.81^{\circ} \mathrm{N}, 111.68^{\circ} \mathrm{E}\right.$; Inner Mongolia Autonomous Region). We used the Gridded Population of the World dataset for 2015 (version 4; http://sedac.ciesin.colu mbia.edu/data/collection/gpw-v4) to calculate the population- weighted $\mathrm{PM}_{2.5}$ concentrations (Text $\mathrm{S} 1$ ) from our simulations to evaluate the effect of ERMs on population health.

\section{Sensitivity Simulations}

We conducted six sensitivity simulations to examine the impacts of the ERMs on air quality in the NCP for December $2-10,2015$. Table 3 summarizes the setup of the sensitivity experiments. The ERM experiment was the control experiment, reflecting our best knowledge of the actual event. We used the simulated differences between the NOERM and the ERM experiments to evaluate the effects of the ERMs on $\mathrm{PM}_{2.5}$ concentrations over the NCP. The simulated differences between the ERM and ERM_NOBJ experiments and the simulated differences between the NOERM and the NOERM_NOBJ experiments indicated the impacts of emissions from Beijing with and without the ERMs, respectively. The simulated differences between the ERM and ERM_NOOTH experiments and the simulated differences between the NOBJ and the NOERM_NOOTH experiments indicated the impacts of emissions from other provinces/cities in the NCP with and without the ERMs, respectively.

\section{RESULTS AND DISCUSSION}

\section{Simulation of the Severe Haze Pollution Event Meteorological Conditions during the Severe Haze Pollution Event}

Fig. 2 shows the observed synoptic meteorological conditions from December 2 to 10, 2015. Between December 2 and 4 (hereafter referred to as the "clean period"), the NCP was affected by a mid-latitude cyclone moving across northeastern China to northern Japan. The passage of the cold front and the intrusion of cold, clean air masses ventilated the boundary layer over the NCP with northwesterly winds, resulting in the lower $\mathrm{PM}_{2.5}$ concentrations $\left(<60 \mu \mathrm{g} \mathrm{m}^{-3}\right)$ during this period. During Stage I (from 16:00 UTC on December 6 until 23:00 UTC on December 7), the NCP was under the influence of a stagnant high-pressure system, which led to weak southwesterly winds, compressed boundary layer, and consequently the accumulation of $\mathrm{PM}_{2.5}$ over the NCP. During Stage II (from 23:00 UTC on December 7 until 04:00 UTC on December 10), the conditions over the NCP continued to be stagnant with high relative humidity, which was not only unfavorable to pollutant dispersion but also conducive to secondary $\mathrm{PM}_{2.5}$ production. Finally, on December 10, a weak cold front passed through the NCP and ventilated the boundary layer, terminating the severe haze event.

Table 3. Design of the sensitivity experiments used in this study.

\begin{tabular}{ll}
\hline Experiments & Emission scenario \\
\hline NOERM & Chinese anthropogenic emissions taken from the MEIC inventory with no reduction \\
ERM (control) & $\begin{array}{l}\text { Same as NOERM, except anthropogenic emissions reduced in Beijing, Tianjin, Hebei, Henan, } \\
\text { and Shandong during December } 6 \text { to } 10 \text { (Stages I and II) as a result of the enforcement of the }\end{array}$ \\
& ERMs (Table 2) \\
ERM_NOBJ & Same as ERM except no anthropogenic emissions in Beijing \\
ERM_NOOTH & Same as ERM except no anthropogenic emissions in Tianjin, Hebei, Henan, and Shandong \\
NOERM_NOBJ & Same as NOERM except no anthropogenic emissions in Beijing \\
NOERM_NOOTH & Same as NOERM except no anthropogenic emissions in Tianjin, Hebei, Henan, and Shandong \\
\hline
\end{tabular}



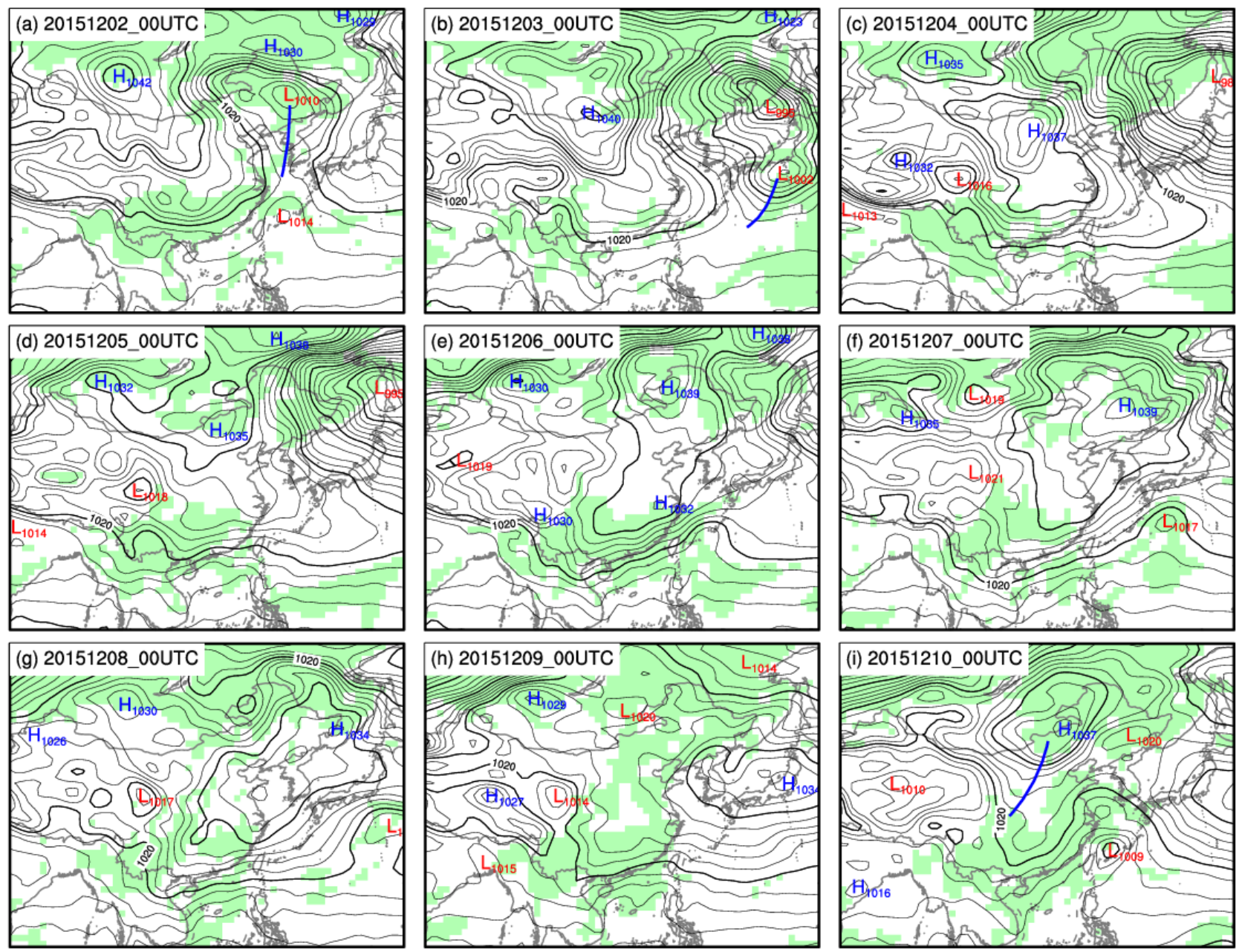

Fig. 2. Meteorological conditions over East Asia during December 2 to 10, 2015 from the FNL reanalysis. Black contours indicate sea level pressure (in hPa). Bold blue lines indicate cold fronts. Color-shaded areas indicate surface relative humidity $>80 \%$.

We verified that the model correctly simulated the progression of the meteorological conditions associated with the haze event from December 2 to 10, 2015. Fig. S2 shows that our model correctly reproduced the observed changes in the planetary boundary layer heights (PBLHs) around the NCP from $>1 \mathrm{~km}$ during the clean period to $0.1-0.8 \mathrm{~km}$ during the polluted period. The simulated surface temperatures, relative humidity, wind speeds, and wind directions also agreed well with observations at the Beijing Capital International Airport (BCIA; $40.08^{\circ} \mathrm{N}, 116.59^{\circ} \mathrm{E}$; Fig. S3) and at other surface sites in the NCP (not shown).

\section{Observed and Simulated Surface PM 2.5 over the NCP}

Fig. 3 shows the observed hourly surface $\mathrm{PM}_{2.5}$ concentrations averaged over sites in Beijing, Tianjin, Hebei, Henan, and Shandong, respectively. From December 2 to 4 , the observed $\mathrm{PM}_{2.5}$ concentrations across the $\mathrm{NCP}$ were generally less than $80 \mu \mathrm{g} \mathrm{m}^{-3}$. Observed $\mathrm{PM}_{2.5}$ concentration began to rise on December 5 and continued to do so through Stages I and II, peaking at approximately $300 \mu \mathrm{g} \mathrm{m}^{-3}$ on December 9 in most cities and provinces in the NCP. The exception was Shandong Province, where the observed
$\mathrm{PM}_{2.5}$ peaked at approximately $200 \mu \mathrm{g} \mathrm{m}^{-3}$ on December 10 .

Fig. 3 also shows the simulated surface $\mathrm{PM}_{2.5}$ concentrations at the five cities and provinces in the NCP using the reduced anthropogenic emissions associated with the ERMs. Our simulation captured the temporal variation of $\mathrm{PM}_{2.5}$ between December 2 and 10 in Beijing, Tianjin, Hebei, Henan, and Shandong. The correlation coefficients $(\mathrm{R})$ between the observed and simulated hourly $\mathrm{PM}_{2.5}$ concentrations ranged from 0.80 to 0.95 for the five cities and provinces. The model showed good skill in reproducing the observed $\mathrm{PM}_{2.5}$ concentrations in Beijing, Hebei, and Henan. The model overestimated the $\mathrm{PM}_{2.5}$ concentrations during the polluted period in Tianjin and Shandong by $40 \%$ and $50 \%$, respectively, likely due to an overestimation of local anthropogenic emissions.

Fig. 4(a) compares the spatial distribution of the simulated surface $\mathrm{PM}_{2.5}$ concentrations in the ERM experiment during Stages I and II against those observed. The spatial distribution of the simulated $\mathrm{PM}_{2.5}$ concentrations was consistent with that of the observations, with high $\mathrm{PM}_{2.5}$ concentrations exceeding $200 \mu \mathrm{g} \mathrm{m}^{-3}$ extending from Henan Province northward to Beijing. In Fig. 4(a), the simulation showed a 


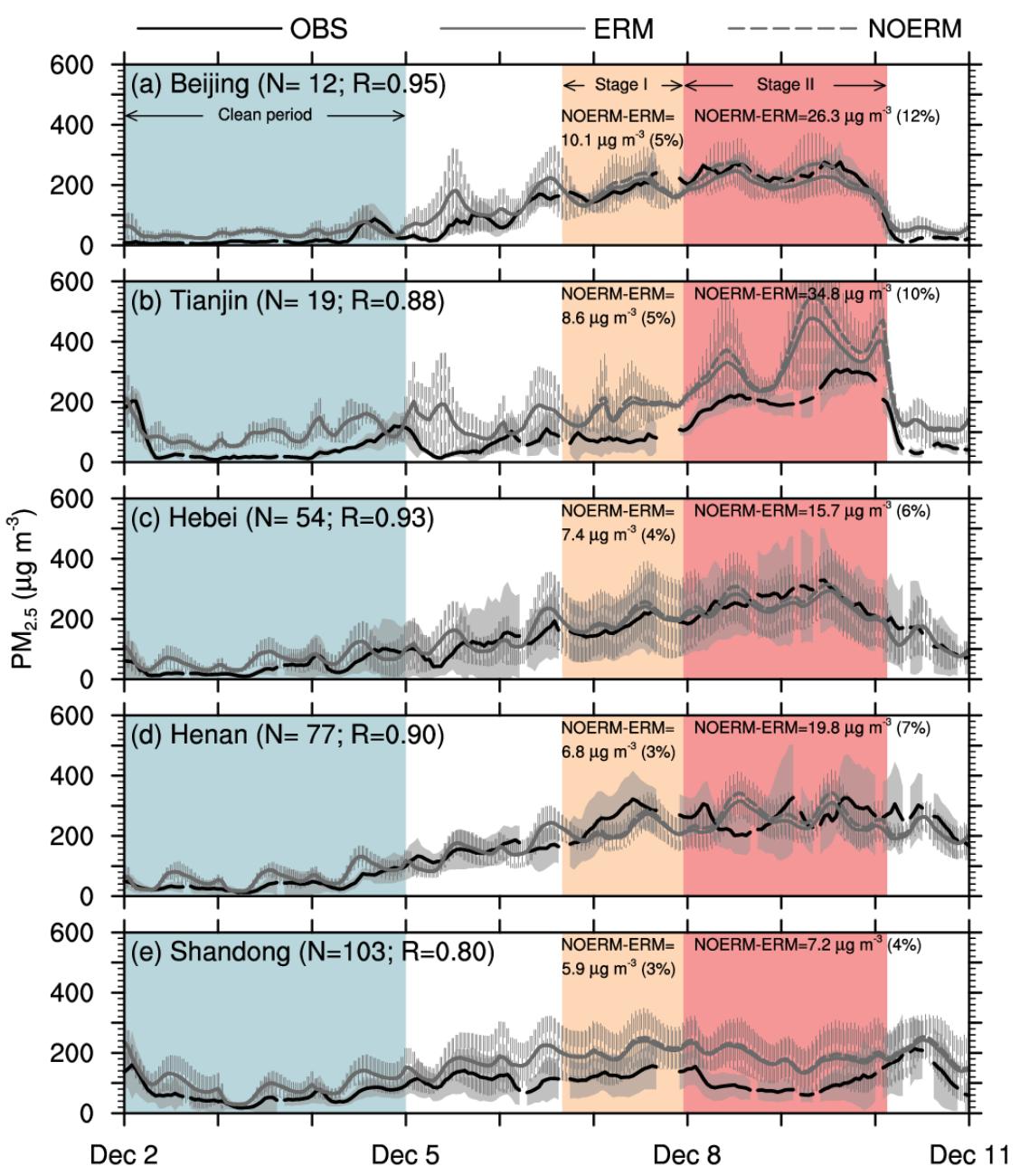

Fig. 3. Observed (black solid line) and simulated surface $\mathrm{PM}_{2.5}$ concentrations (as average concentrations sampled at surface sites) in (a) Beijing, (b) Tianjin, (c) Hebei, (d) Henan, and (e) Shandong during December 2 to 10, 2015. Simulated concentrations from the NOERM and ERM experiments are shown in dashed grey lines and solid grey lines, respectively. The error bar represents one standard deviation. The site numbers in each province/city $(\mathrm{N})$, the correlation coefficients $(\mathrm{R})$ between the observed concentrations and those simulated in the ERM experiment, simulated concentration differences between the two experiments, as well as the simulated concentration difference percentages between the two experiments are shown inset. The clean period, Stage I, and Stage II are shaded in blue, orange, and red, respectively.

hot spot in Tianjin that was not in the observation, likely indicating an overestimation of industrial emissions in Tianjin.

Fig. 5 further compares the simulated $\mathrm{PM}_{2.5}$ concentrations and compositions from the ERM experiment against measurements at the CRAES and PKUERS sites in Beijing from December 2 to 10,2015 . The simulated $\mathrm{PM}_{2.5}$ concentrations in the ERM experiment agreed well with the measurements at the CRAES site (Fig. 5(a)). The model captured the relatively low $\mathrm{PM}_{2.5}$ concentrations from December 2 to 5 , the rise of $\mathrm{PM}_{2.5}$ concentrations from December 5 to 10 , as well as the sharp decline of $\mathrm{PM}_{2.5}$ concentrations on December 10. The simulated peak $\mathrm{PM}_{2.5}$ concentration of $308 \mu \mathrm{g} \mathrm{m}^{-3}$ was also in good agreement with the observation $\left(317 \mu \mathrm{g} \mathrm{m}^{-3}\right)$. Fig. 5(c) showed the observed average daily $\mathrm{PM}_{2.5}$ compositions at the PKUERS site in Beijing for December 6-10. OA (including primary and secondary $\mathrm{OA}$ ) was the largest chemical component in
$\mathrm{PM}_{2.5}$ measured at PKUERS, constituting $33 \%$ of the total $\mathrm{PM}_{2.5}$ mass. This was followed by nitrate, sulfate, and ammonium, contributing $18 \%, 15 \%$, and $11 \%$ of the total $\mathrm{PM}_{2.5}$ mass, respectively. At PKUERS, $19 \%$ of the observed total $\mathrm{PM}_{2.5}$ mass was unidentified, most likely constituted of dust. Fig. 5(d) shows our simulated $\mathrm{PM}_{2.5}$ compositions in the ERM experiment, which were in good agreement with the measurements. The model also indicated OA as the largest chemical component, followed by nitrate, sulfate, and ammonium. Our simulation indicated that $58 \%$ of the simulated $\mathrm{PM}_{2.5}$ was of secondary origin, consistent with previous measurement studies which found that more than half of the $\mathrm{PM}_{2.5}$ in Beijing during severe wintertime haze events was secondary (Huang et al., 2014).

To better understand the cause of the severe haze event, we examined the lifetime of $\mathrm{PM}_{2.5}(\tau)$ in the boundary layer of the NCP. For a species in a well-defined reservoir, the mass balance equation is (Jacob, 1999): 


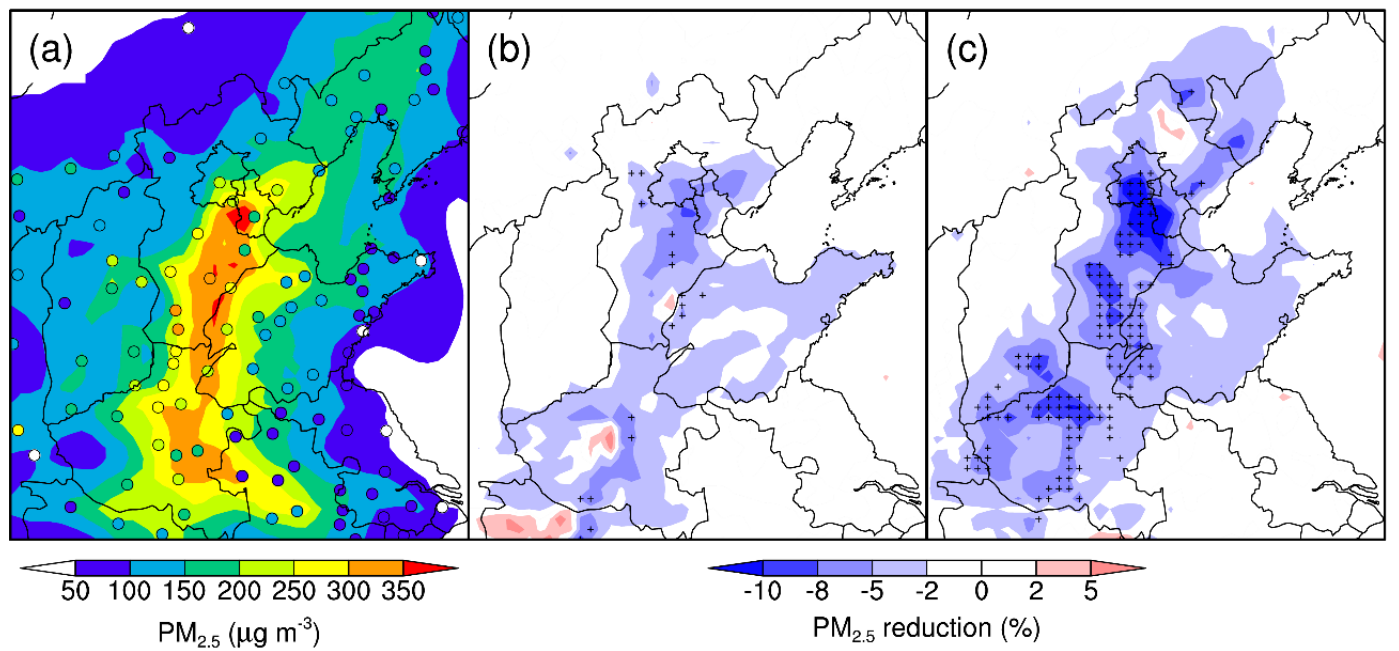

Fig. 4. (a) Spatial distribution of the simulated mean surface $\mathrm{PM}_{2.5}$ concentrations over NCP during Stage I and Stage II from the ERM experiment, overlaid with the mean concentrations observed at surface sites (filled circles). The percentage of $\mathrm{PM}_{2.5}$ concentration changes due to the enforcement of the ERMs during (b) Stage I and (c) Stage II. Grids marked with "+" indicate changes that are statistically significant relative to the hourly concentration variability $(\alpha=0.05)$.

$$
\frac{d m}{d t}=\sum \text { sources }+\sum \operatorname{sinks}
$$

where $m$ is the mass of the species in the reservoir, $d m / d t$ is the rate of mass change, and $\sum$ sources and $\sum$ sinks are the total sources and total sinks of the species, respectively. The residence time of the species in the reservoir is defined as $\tau$ $\equiv m / \sum$ sinks (Jacob, 1999). In the case of $\mathrm{PM}_{2.5}$ in the boundary layer of the NCP:

$$
\tau \equiv \frac{m}{\sum \operatorname{sinks}}=\frac{m}{L_{h-o u t}+L_{v-o u t}+L_{\text {drydep }}+L_{\text {wetscav }}+L_{\text {chem }}}
$$

where $m$ was the total $\mathrm{PM}_{2.5}$ mass in the atmospheric boundary layer of the NCP. The denominator in Eq. (3) was the sum of rates of $\mathrm{PM}_{2.5}$ mass removal from the $\mathrm{NCP}$ boundary layer, which included removal by horizontal ventilation $\left(L_{h \text {-out }}\right)$, vertical ventilation $\left(L_{v \text {-out }}\right.$; including large-scale vertical advection and convective transport), dry deposition $\left(L_{\text {drydep }}\right)$, wet scavenging $\left(L_{\text {wetscav }}\right)$, and chemical loss $\left(L_{c h e m}\right)$. We diagnosed the individual terms in Eq. (3) using the NOERM simulation for the clean and polluted periods, respectively (Table S3). There was no rainfall over the NCP during both periods, so $L_{\text {wetscav }}$ was 0 . The chemical loss of $\mathrm{PM}_{2.5}\left(L_{\text {chem }}\right)$ has been shown to be two orders of magnitude smaller than the removal rates of ventilation and deposition, especially in winter (Guth et al., 2018; Huang et al., 2019). The simulated mass of $\mathrm{PM}_{2.5}$ in the boundary layer of the NCP averaged during the clean and polluted periods were $7.3 \times 10^{16} \mu \mathrm{g}$ and $1.0 \times 10^{17} \mu \mathrm{g}$, respectively.

During the clean period, horizontal ventilation by the northwesterly wind was strong throughout the NCP. By applying the numbers in Table S3 into Eq. (3), we estimated a lifetime of 0.9 days for $\mathrm{PM}_{2.5}$ in the boundary layer of the
NCP. In comparison, the horizontal ventilation of $\mathrm{PM}_{2.5}$ was much weaker under the stagnant conditions during the polluted period. As such, the lifetime of $\mathrm{PM}_{2.5}$ in the boundary layer of the NCP during the polluted period (Stages I and II) dramatically lengthened to 4.8 days. This led to significant accumulation of $\mathrm{PM}_{2.5}$ in the boundary layer of the NCP.

\section{Effects of the ERMs on Surface PM ${ }_{2.5}$ Concentrations over the $\mathrm{NCP}$}

Figs. 4(b) and 4(c) show the differences in simulated surface $\mathrm{PM}_{2.5}$ concentrations between the NOERM and the ERM experiments during Stages I and II, which represent the effects of the ERMs on surface $\mathrm{PM}_{2.5}$ concentrations. During Stage I (Fig. 4(b)), most areas across the NCP saw only a $2-8 \%$ decline in surface $\mathrm{PM}_{2.5}$ as a result of the ERMs. During Stage II, the decline of $\mathrm{PM}_{2.5}$ exceeded $8 \%$ and was statistically significant (relative to the hourly variability) around Beijing, Tianjin, and the industrial areas of southern Hebei and northern Henan. The decrease of $\mathrm{PM}_{2.5}$ was much smaller over Shandong, where the reduction in anthropogenic pollutant emissions associated with ERMs was less than $10 \%$ (Table 2). Overall, the effects of the ERMs were modest, reducing the mean $\mathrm{PM}_{2.5}$ over the NCP by $2.5 \%$ during Stage I and by $4.2 \%$ during Stage II.

Fig. 5(a) compares the simulated $\mathrm{PM}_{2.5}$ concentrations in the NOERM and ERM experiments at the CRAES site in Beijing. The mean abatements in the simulated $\mathrm{PM}_{2.5}$ concentrations at this site due to the ERMs were 3\% and $10 \%$ during Stage I and Stage II, respectively. The largest simulated abatement of $11 \%$ occurred on December 9, reflecting the cumulative effect of emission reductions up to that time. Fig. 5(b) shows the reduction of individual $\mathrm{PM}_{2.5}$ components at the CRAES site. The reduction in secondary aerosols accounted for over $53 \%$ of the total $\mathrm{PM}_{2.5}$ decrease during the polluted period, including most importantly SOA 

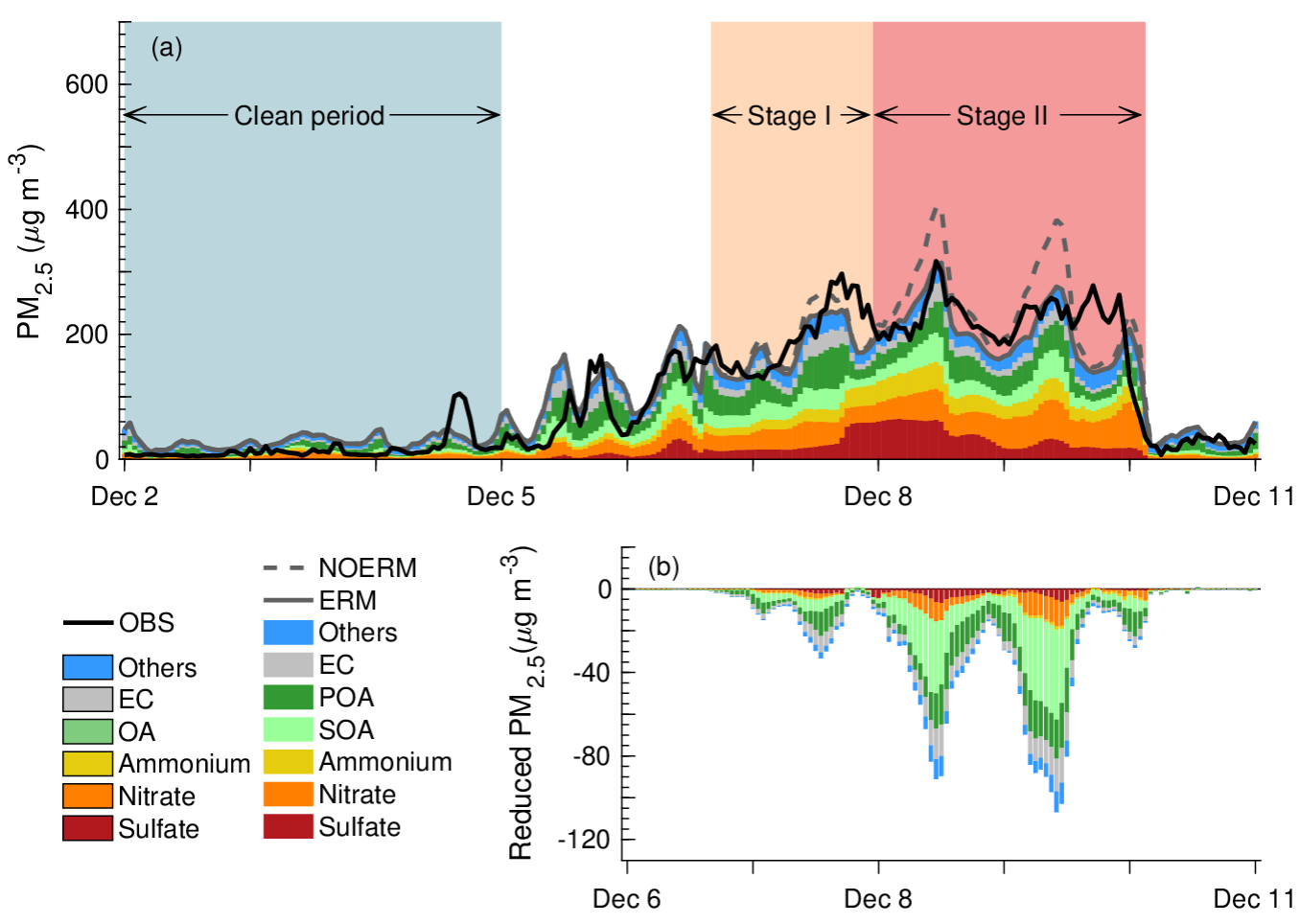

(c) OBS

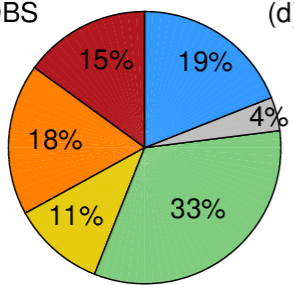

(d) ERM

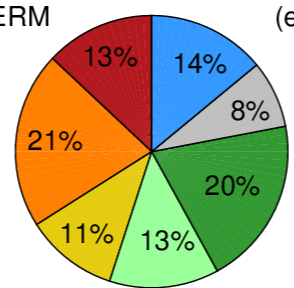

(e) NOERM

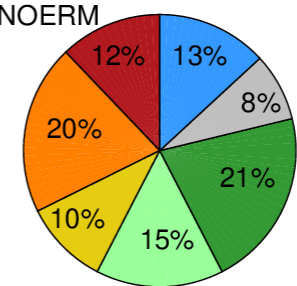

Fig. 5. (a) Temporal variations of $\mathrm{PM}_{2.5}$ concentrations and components in the ERM experiment (solid grey line and colorfilled bars), $\mathrm{PM}_{2.5}$ concentrations in the NOERM experiment (dashed grey line), and the observed $\mathrm{PM}_{2.5}$ concentration (black line) at the CREAS site in Beijing during December 2 to 10, 2015. (b) The differences in the simulated PM 2.5 concentrations and compositions at the CREAS site as a result of the ERMs. Also shown are the (c) observed and simulated $\mathrm{PM}_{2.5}$ compositions in (d) the ERM and (e) the NOERM experiments during December 6 to 10 at the PKUERS site. Chemical compositions are color-coded. "Others" in the observation indicate non-resolved chemical component. "Others" in the simulation indicate the sum of anthropogenic dust, natural dust, and sea salt.

$\left(-10 \mu \mathrm{g} \mathrm{m}^{-3}\right)$. Primary OA and EC were reduced by $8 \mu \mathrm{g} \mathrm{m}^{-3}$ and $5 \mu \mathrm{g} \mathrm{m}^{-3}$, respectively. Although there was a significant reduction of anthropogenic dust emissions due to the ERMs, the resulting change in $\mathrm{PM}_{2.5}$ concentrations attributable to dust was only $7 \%$ due to its small share in the total $\mathrm{PM}_{2.5}$ during the haze event. Figs. 5(c)-5(e) compare the simulated $\mathrm{PM}_{2.5}$ composition in the ERM and NOERM experiments against the observations at the PKUERS site. Although the implementation of ERMs resulted in varying amounts of concentration decrease in different chemical species (Fig. 5(b)), the overall composition in the ERM and NOERM experiments remained similar, as the total $\mathrm{PM}_{2.5}$ concentration reduction was small.

We also calculated the population-weighted $\mathrm{PM}_{2.5}\left(\mathrm{PPM}_{2.5}\right)$ concentrations from our simulations to evaluate the effect of ERMs on population health. Fig. 6 compares the simulated daily $\mathrm{PM}_{2.5}$ concentrations and $\mathrm{PPM}_{2.5}$ concentrations from the NOERM and the ERM experiments for each of the five administrative areas for December 6-10. The mean reductions of $\mathrm{PM}_{2.5}\left(\mathrm{PPM}_{2.5}\right)$ attributable to the ERMs over Beijing, Tianjin, Hebei, Henan and Shandong during the polluted period (Stages I and II) were 7\% (11\%), 7\% (7\%), 5\% (6\%), $4 \%(4 \%)$, and $3 \%(3 \%)$, respectively. The largest decrease of daily $\mathrm{PM}_{2.5}$ was $9 \%$ in Beijing and Tianjin. The largest decrease of daily $\mathrm{PPM}_{2.5}$ of $14 \%$ was also in Beijing, indicating that the benefit of the ERMs in reducing public $\mathrm{PM}_{2.5}$ exposure was greatest in the most densely populated locations.

Overall, the reductions in $\mathrm{PM}_{2.5}$ and $\mathrm{PPM}_{2.5}$ as a result of the ERMs were surprisingly modest in the NCP, considering that the emissions of $\mathrm{PM}_{2.5}$ and its precursors were significantly reduced by $8-48 \%$ due to the implementation of the ERMs (Table 2). In the sections below, we examined the causes for the ineffectiveness of the ERM in reducing $\mathrm{PM}_{2.5}$ concentrations over the NCP during this severe winter haze event. 

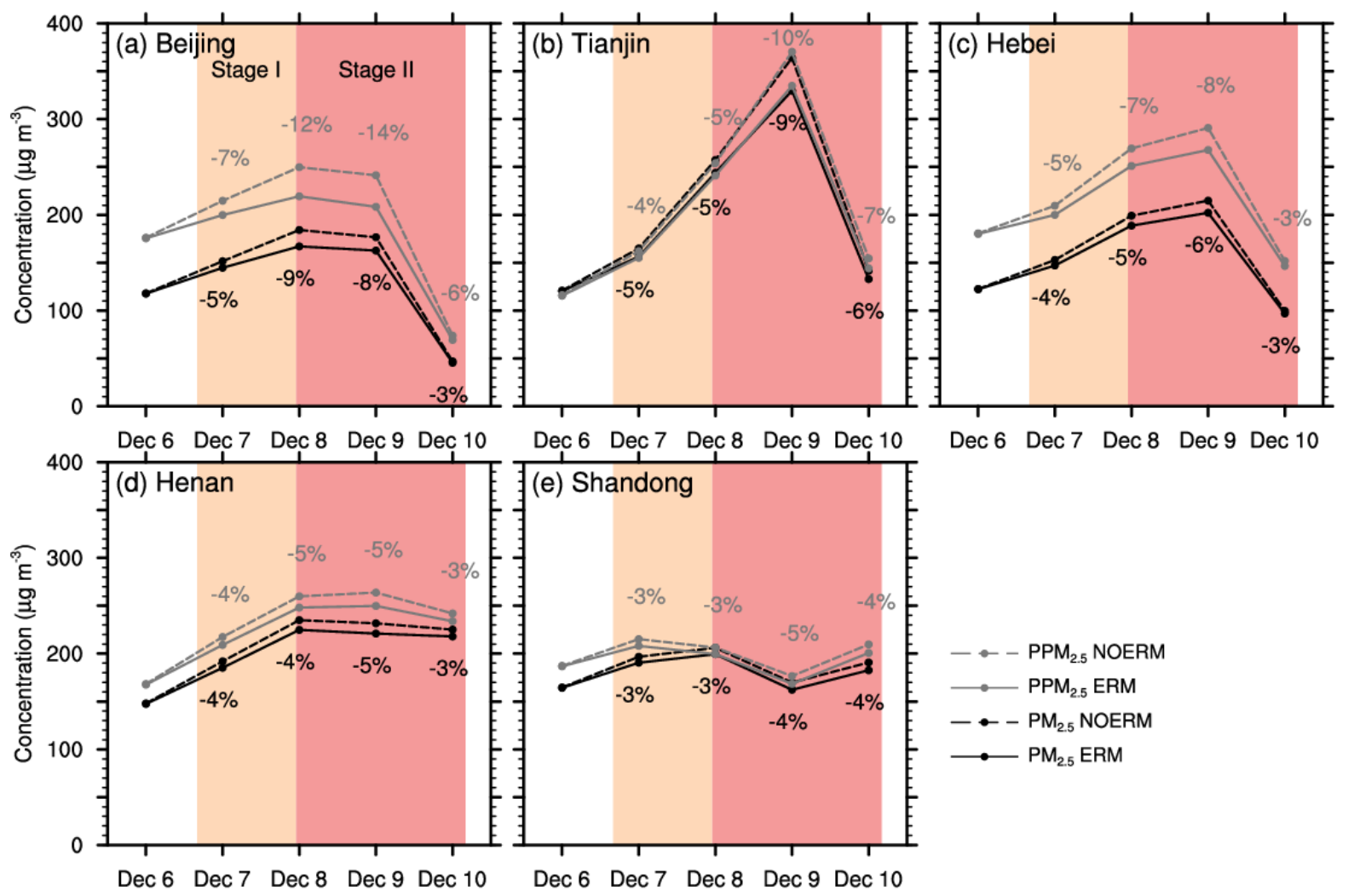

Fig. 6. Daily $\mathrm{PM}_{2.5}$ and population-weighted $\mathrm{PM}_{2.5}\left(\mathrm{PPM}_{2.5}\right.$ ) variations for (a) Beijing, (b) Tianjin, (c) Hebei, (d) Henan and (e) Shandong during the emission reduction period. The duration of Stage I, and Stage II are shaded in orange and red, respectively.

\section{Spatial Source Attribution of PM2.5 in the NCP during Clean and Polluted Periods}

We used sensitivity simulations (Table 3 ) to quantify the relative contributions of local versus regional emissions to $\mathrm{PM}_{2.5}$ concentrations in Beijing and in the rest of the NCP (Tianjin, Hebei, Henan and Shandong) during the severe haze event. Using model simulations driven by Chinese anthropogenic emissions for the year 2010, Zhang et al. (2015) previously found that $50 \%$ of the monthly mean $\mathrm{PM}_{2.5}$ concentration in Beijing in January 2013 was due to emissions within Beijing. However, this number should be re-evaluated, as there have been substantial changes in the annual anthropogenic pollutant emissions in Beijing and its surrounding areas between the 2010 inventory (Zhang et al., 2009; Lei et al., 2011; Lu et al., 2011) used by Zhang et al. (2015) and the 2016 inventory (Li et al., 2017) used in our study (Fig. S4).

Fig. 7(a) shows the percentages of the $\mathrm{PM}_{2.5}$ in Beijing attributable to emissions from Beijing, from the rest of the NCP and from outside the NCP, respectively. During the clean period, $60 \%$ of the simulated mean $\mathrm{PM}_{2.5}$ concentration in Beijing was due to emissions from outside the NCP. This was mostly dust transported to Beijing by northwesterly winds. Pollutants emitted within Beijing and pollutants emitted from the rest of the NCP contributed only $25 \%$ and $15 \%$ of the $\mathrm{PM}_{2.5}$ in Beijing, respectively, during the clean period. During polluted periods and based on the NOERM simulation, pollutants emitted within Beijing contributed only $18-22 \%$ of the $\mathrm{PM}_{2.5}$ in Beijing during Stages I and II, much lower than the $50 \%$ inferred by Zhang et al. (2015) for January 2013. In comparison, pollutants emitted from the rest of the NCP and from outside the NCP contributed 49$58 \%$ and $23-29 \%$ of the $\mathrm{PM}_{2.5}$ in Beijing, respectively. However, Han and Zhang (2017) got similar results in July 2015 that Beijing local emissions contributed 20-30\% to the $\mathrm{PM}_{2.5}$ concentrations in Beijing and the surrounding regions contributed the majority. The large contribution of pollutants emitted from outside Beijing to the $\mathrm{PM}_{2.5}$ in Beijing during the severe haze event reflected the regional stagnant weather, which enabled the accumulation of pollutants over the entire NCP.

Due to the implementation of ERMs, the simulated mean $\mathrm{PM}_{2.5}$ concentrations in Beijing decreased by $4 \%$ and $9 \%$ relative to the NOERM case during Stages I and II, respectively. During Stage I, the decrease was due to the combined effects of ERMs implemented in Beijing (2\%) and in the rest of the NCP (2\%). During Stage II, the decrease was mostly due to the combined effects of ERMs implemented in Beijing (5\%) and the rest of the NCP (3\%). A remaining $1 \%$ decrease of the $\mathrm{PM}_{2.5}$ concentration in Beijing during State II was due to small nonlinearity in the $\mathrm{PM}_{2.5}$ production. We will return to this point later.

Fig. 7(b) shows the simulated attribution of the mean $\mathrm{PM}_{2.5}$ concentration in the rest of the NCP. Under both clean and polluted conditions, more than $62 \%$ of the mean $\mathrm{PM}_{2.5}$ concentrations in the rest of the NCP was from local emissions, 

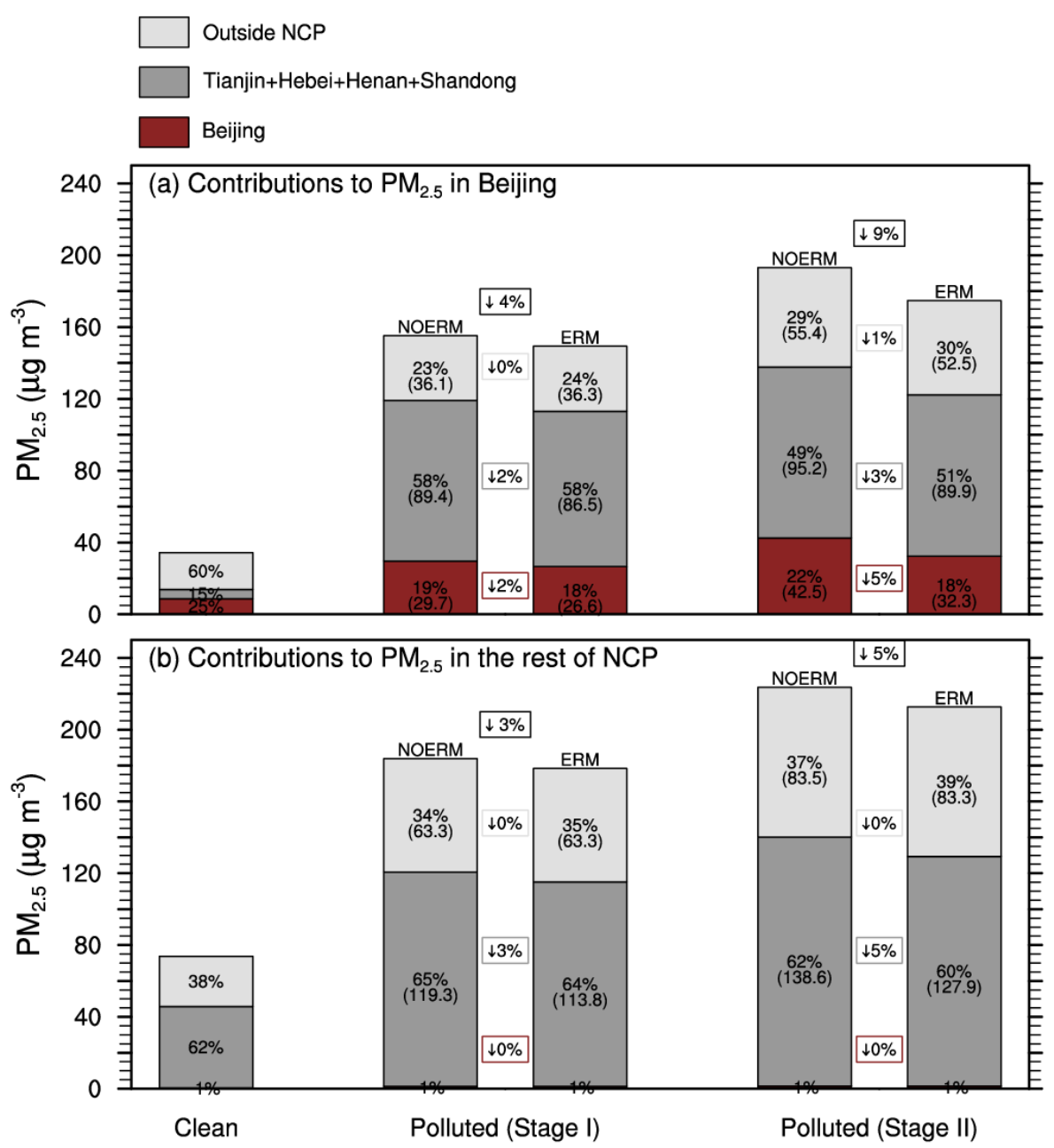

Fig. 7. Simulated contributions of local versus regional emissions to $\mathrm{PM}_{2.5}$ concentrations in (a) Beijing and (b) the rest of the NCP during the clean period and during the polluted period (Stages I and II). Concentrations and percent contributions from Beijing (red), from the other municipalities within the NCP (dark grey), and from outside the NCP (light grey) are shown inset.

while $34-37 \%$ was attributed to emissions from outside the NCP. Contributions from Beijing were small throughout the study period. The simulated mean concentrations of $\mathrm{PM}_{2.5}$ in the rest of the NCP decreased by $3 \%$ and $5 \%$ in the ERM case relative to the NOERM case during Stages I and II, respectively. All of the simulated abatements in $\mathrm{PM}_{2.5}$ were attributed to emission reductions in the rest of the NCP.

Our sensitivity simulations used the "emission zero-out" approach to quantify the percentage contribution of a particular source area to the $\mathrm{PM}_{2.5}$ concentration in a receptor area. For example, we compared the simulated Beijing $\mathrm{PM}_{2.5}$ concentrations between the ERM and ERM_NOOTH experiments to quantify the contribution of emissions from the rest of the NCP to the $\mathrm{PM}_{2.5}$ concentrations in Beijing. One concern for this approach is that secondary $\mathrm{PM}_{2.5}$ production is nonlinear, and that zeroing out the emissions from a source area may cause nonlinear chemical responses to the simulated $\mathrm{PM}_{2.5}$ concentrations in the receptor area. Another potential source of nonlinearity involves the feedback between $\mathrm{PM}_{2.5}$ and meteorology, but that was not an issue in our case because our WRF-Chem simulations were nudged with meteorological observations. We found however, that the overall nonlinear chemical responses were small in this particular pollution event. Using the emission zero-out approach, we estimated that the pollutants from Beijing and from the rest of the NCP contributed $29.7 \mu \mathrm{g} \mathrm{m}^{-3}$ and $89.4 \mu \mathrm{g} \mathrm{m}^{-3}$ of $\mathrm{PM}_{2.5}$ in Beijing under the NOERM scenario during Stage I (Fig. 7(a)). This meant that the $\mathrm{PM}_{2.5}$ contributed from outside the NCP was $36.1 \mu \mathrm{g} \mathrm{m}^{-3}$ under the NOERM scenario during Stage I. Under the ERM scenario, we similarly calculated a $36.3 \mu \mathrm{g} \mathrm{m}^{-3}$ contribution from outside the NCP. This indicated that, during this particular pollution event, there was no strong nonlinearity in $\mathrm{PM}_{2.5}$ production, otherwise the perturbation in emissions by the ERM enforcement would have led to differences in the calculated contribution from outside the NCP, where no control measures were implemented. We further compared the sensitivity simulations for Beijing and for the NCP during Stages I and II. Overall, the chemical nonlinearity accounted for, at most, a $1 \%$ decrease in the $\mathrm{PM}_{2.5}$ concentration in Beijing during Stage II under the ERM scenario. This small nonlinearity did not change our overall source attribution. 


\section{Cause of the Ineffectiveness of the ERMs during the Severe Haze Event of December 6-10, 2015}

We analytically examined the cause of the ineffectiveness of the ERMs in abating surface $\mathrm{PM}_{2.5}$ concentrations over the NCP from December 6 to 10, 2015. Without the ERMs implemented, the daily source of $\mathrm{PM}_{2.5}$ contributed by source area $j$ to a specific receptor area $i$ during the polluted period was $S_{\mathrm{NOERM}, i, j}\left(\mu \mathrm{g} \mathrm{m}^{-3} \mathrm{day}^{-1}\right)$, which included contributions both primary and secondary from source area $j$. The total daily $\mathrm{PM}_{2.5}$ source for a receptor area $i\left(S_{\mathrm{NOERM}, i}\right)$ was the sum of $S_{\mathrm{NOERM}, i, j}$ over all values of $j$. In our case, $j=1-3$, indicating contributions from Beijing $(j=1)$, from the rest of the NCP $(j=2)$, and from all other regions outside the $\operatorname{NCP}(j=3)$, respectively:

$S_{\mathrm{NOERM}, i}=\sum_{j=1}^{3} S_{\mathrm{NOERM}, i, j}$

The individual $S_{\mathrm{NOERM}, i, j}$ can also be expressed as:

$S_{\mathrm{NOERM}, i, j}=g_{i . j} \cdot S_{\mathrm{NOERM}, i}$

where $g_{i, j}$ was the fractional contribution of pollutants from source area $j$ to surface $\mathrm{PM}_{2.5}$ in receptor area $i$. The values $g_{i, j}$ for $j=1,3$ were given by the source attribution in Section 5 (Fig. 7). For the receptor area Beijing, the values of $g_{i, j}$ for $j=1,3$ were $0.19,0.58$, and 0.23 during Stage I and 0.22, 0.49 , and 0.29 during Stage II. Similarly, for the receptor area of the rest of the NCP, the values of $g_{i, j}$ for $j=1,3$ were $0.01,0.65$, and 0.34 during Stage I and 0.01, 0.62, and 0.37 during Stage II.

For a well-defined receptor area $i, S_{\mathrm{NOERM}, i}$ was also equal to the sum of the inflow of $\mathrm{PM}_{2.5}$ from other source areas, the local primary $\mathrm{PM}_{2.5}$ emissions, and the local chemical production of secondary $\mathrm{PM}_{2.5}$ :

$S_{\mathrm{NOERM}, i}=\mathrm{S}_{\mathrm{NOERM}, i} \mid \mathrm{PM}_{2.5}$ inflow $+S_{\mathrm{NOERM}, i}||_{\text {local primary } \mathrm{PM}_{2.5} \text { emis }}+$

$\left.S_{\text {NOERM }, i}\right|_{\text {local secondary }} \mathrm{PM}_{2.5}$ prod

The first two terms on the right-hand side in Eq. (4) can be directly calculated from our NOERM simulation. The third term involves the efficiencies at which precursors were converted to secondary $\mathrm{PM}_{2.5}$. We estimate this third term using the simulated local conversion ratios of individual anthropogenic precursors to their respective secondary aerosol products. For example, we used the simulated local sulfur oxidation ratio $(\mathrm{SOR}) \equiv\left[\mathrm{SO}_{4}{ }^{2-}(\mathrm{a})\right] /\left(\left[\mathrm{SO}_{4}{ }^{2-}(\mathrm{a})\right]+\left[\mathrm{SO}_{2}(\mathrm{~g})\right]\right)$ to estimate the local conversion efficiency of $\mathrm{SO}_{2}$ to sulfate (Fang et al., 2017). Similarly, the local nitrogen oxidation ratio (NOR), the local ammonia conversion ratio (NHR), and the anthropogenic VOC oxidation ratio (VOR) were calculated from our NOERM simulation (Fang et al., 2017). The definitions and values of these ratios are shown in Table S4. Our simulated SOR, NOR, and NHR values were in the range of values previously reported in wintertime observation studies over the NCP (Liu et al., 2020). Using the model emissions and the values in Table S4, we estimated the third term on the right-hand side of Eq. (4) as:

$\left.S_{\mathrm{NOERM}, i}\right|_{\text {local secondary } \mathrm{PM}_{2.5} \text { prod }}=E_{\mathrm{SO}_{2}, i} \cdot \mathrm{SOR}_{i}+E_{\mathrm{NO}_{x}, i} \cdot \mathrm{NOR}_{i}+$

$E_{\mathrm{NH} 3, i} \cdot \mathrm{NHR}_{i}+E_{\mathrm{VOC}, i} \cdot \mathrm{VOR}_{i}$

Using the NOERM simulated results to calculate the values in Eqs. (4) and (5), we estimated $S_{\mathrm{NOERM}, i}$ to be $68 \mu \mathrm{g} \mathrm{m}^{-3}$ day $^{-1}$ in Beijing and $76 \mu \mathrm{g} \mathrm{m}^{-3} \mathrm{day}^{-1}$ for the rest of the NCP during the polluted period.

We assumed that the transport pathways and transport efficiencies of $\mathrm{PM}_{2.5}$ and the production efficiencies of secondary $\mathrm{PM}_{2.5}$ from precursors during the polluted period were similar with and without the implementation of ERMs for a given period, i.e., we assumed that the values of $g_{i, j}$ and the conversion ratios in Table S4 were similar with and without the implementation of ERMs for a given period. This is a reasonable assumption given that the simulated impacts of the ERMs on $\mathrm{PM}_{2.5}$ concentrations were small across the NCP. Also, our sensitivity simulations indeed showed the source attributions $\left(g_{i, j}\right)$ to be very similar with and without the ERMs (Fig. 7). Then, the fractional abatement of the total $\mathrm{PM}_{2.5}$ source contributed from source area $j$ to any other receptor area, $\alpha_{j}$, was:

$\alpha_{j}=\frac{S_{\mathrm{NOERM}, i, j}-S_{\mathrm{ERM}, i, j}}{S_{\mathrm{NOERM}, i, j}}=\frac{E_{\mathrm{NOERM}, j}-E_{\mathrm{ERM}, j}}{E_{\mathrm{NOERM}, j}}$

where $S_{\mathrm{ERM}, i, j}$ was the daily source of $\mathrm{PM}_{2.5}$ contributed by source area $j$ to a specific receptor area $i$ during the polluted period with the ERMs implemented. $E_{\mathrm{NOERM}, j}$ and $E_{\mathrm{ERM}, j}$ were the emission rates of precursors from source area $j$. Table 2 shows the emission reduction percentages of primary $\mathrm{PM}_{2.5}$ and precursors to be in the range of $4 \%$ and $15 \%$ during Stage I. We estimated the overall $\alpha_{j}$ by weighting the precursor emission reduction percentages with the simulated composition of $\mathrm{PM}_{2.5}$ (Fig. 5(e)). In this way, we estimated $\alpha_{j}$ to be $12 \%$ and $34 \%$ for Beijing during Stages I and II, respectively. Using the same method, the values of $\alpha_{j}$ were estimated to be $11 \%$ and $14 \%$ for the rest of NCP during Stages I and II, respectively.

Finally, if the ERMs were implemented, the total daily source of $\mathrm{PM}_{2.5}$ in area $i$ during the polluted period was $S_{\mathrm{ERM}, i}$ :

$S_{\mathrm{ERM}, j}=\sum_{j=1}^{3}\left[\left(1-\alpha_{j}\right) \cdot g_{i, j}\right] \cdot S_{\mathrm{NOERM}, i}$

For region $i$ and from an initial $\mathrm{PM}_{2.5}$ concentration $c_{i}(t=$ $\left.t_{0}\right)$ in the boundary layer, if ERMs were not implemented, the $\mathrm{PM}_{2.5}$ concentration $\left(c_{\mathrm{NOERM}, i}\right)$ at time $t=t_{0}+\Delta t$ during the polluted period was (Jacob, 1999):

$c_{\mathrm{NOERM}, i}\left(t_{0}+\Delta t\right)=c_{i}\left(t_{0}\right) \cdot e^{-\Delta t / \tau_{i}}+S_{\mathrm{NOERM}, i} \cdot \tau_{i}\left(1-e^{-\Delta t / \tau_{i}}\right)$

where $\tau_{i}$ is the lifetime of $\mathrm{PM}_{2.5}$ in region $i$, which was 4.8 days throughout the NCP during the polluted period. If ERMs were implemented, the $\mathrm{PM}_{2.5}$ concentration $\left(c_{\mathrm{ERM}, i}\right)$ at 
time $t=t_{0}+\Delta t$ during the polluted period was:

$c_{\mathrm{ERM}, i}\left(t_{0}+\Delta t\right)=c_{i}\left(t_{0}\right) \cdot e^{-\Delta t / \tau_{i}}+S_{\mathrm{ERM}, i} \cdot \tau_{i}\left(1-e^{-\Delta t / \tau_{i}}\right)$

Eqs. (8) and (9) thus give the analytical solution of how the $\mathrm{PM}_{2.5}$ concentrations change with time given the initial concentration $\left(c_{i}\left(t_{0}\right)\right)$, the $\mathrm{PM}_{2.5}$ source $\left(S_{\mathrm{NOERM}, i}\right.$ or $\left.S_{\mathrm{ERM}, i}\right)$, and the lifetime of $\mathrm{PM}_{2.5}\left(\tau_{i}\right)$ in the reservoir (boundary layer of NCP). At time $t=t_{0}+\Delta t$, the analytical solution of the fractional abatement of $\mathrm{PM}_{2.5}$ in area $i$ associated with the implementation of the NCP-wide ERMs was:

$f_{i}=\frac{c_{\mathrm{NOERM}, i}\left(t_{0}+\Delta t\right)-c_{\mathrm{ERM}, i}\left(t_{0}+\Delta t\right)}{c_{\mathrm{NOERM}, i}\left(t_{0}+\Delta t\right)}$

where $c_{\mathrm{NOERM}, i}\left(t_{0}+\Delta t\right)$ and $c_{\mathrm{ERM}, i}\left(t_{0}+\Delta t\right)$ were described analytically by Eqs. (8) and (9), respectively.

Using Eqs. (8), (9), and (10), we can analytically compute the fractional abatements of $\mathrm{PM}_{2.5}$ concentrations $\left(f_{i}\right)$ in Beijing and in the rest of the NCP as a result of the enforced ERMs, as functions of days since the initiation of the ERM enforcement $(\Delta t)$. The results are shown in Fig. 8. The fractional abatements of $\mathrm{PM}_{2.5}$ gradually become more evident over time. The rates of changes of $f_{i}$ were determined not only by the emission reductions, but also by the lifetimes of $\mathrm{PM}_{2.5}$, as indicated in Eqs. (8)-(10). In Beijing, the mean analytical fractional abatements of $\mathrm{PM}_{2.5}$ during Stages I and II were $4 \%$ and $9 \%$, respectively (Fig. 8(a)). In the rest of the NCP, the mean analytical fractional abatement of $\mathrm{PM}_{2.5}$ during Stages I and II were $3 \%$ and $6 \%$, respectively (Fig. 8(b)). These analytically calculated mean fractional abatements of $\mathrm{PM}_{2.5}$ were consistent with our simulated results in Section 3.3.

As calculated in Section 3.1.2, the lifetime of $\mathrm{PM}_{2.5}$ in the boundary layer of the entire NCP $\left(\tau_{i}\right)$ was 4.8 days during the polluted periods. Hypothetically, if the lifetime of $\mathrm{PM}_{2.5}$ was very short, or if the ERMs were enforced for a duration ( $\Delta t$ ) much longer than $\tau_{i}$, then $\Delta t / \tau_{i} \rightarrow \infty$ and $\exp \left(-\Delta t / \tau_{i}\right)$ would approach 0 in Eqs. (8) and (9). Under this hypothetical situation, the fractional abatement $\left(f_{i}\right)$ of $\mathrm{PM}_{2.5}$ in area $i$ associated with the implementation of the NCP-wide ERMs would approach a maximum, $f_{\max , i}$ :

$$
\begin{aligned}
& f_{\mathrm{max}, i}=\frac{m_{\mathrm{NOERM}, i}(\infty)-m_{\mathrm{ERM}, i}(\infty)}{m_{\mathrm{NOERM}, i}(\infty)} \\
& c_{i}\left(t_{0}\right) \cdot e^{-\infty}+S_{\mathrm{NOERM}, i} \cdot \tau_{i}\left(1-e^{-\infty}\right) \\
& =\frac{-\left[c_{i}\left(t_{0}\right) \cdot e^{-\infty}+S_{\mathrm{ERM}, i} \cdot \tau_{i}\left(1-e^{-\infty}\right)\right]}{c_{i}\left(t_{0}\right) \cdot e^{-\infty}+S_{\mathrm{NOERM}, i} \cdot \tau_{i}\left(1-e^{-\infty}\right)} \\
& \rightarrow \frac{S_{\mathrm{NOERM}, i}-S_{\mathrm{ERM}, i}}{S_{\mathrm{NOERM}, i}}=1-\sum_{j=1}^{3}\left[\left(1-\alpha_{j}\right) \cdot g_{i . j}\right]
\end{aligned}
$$

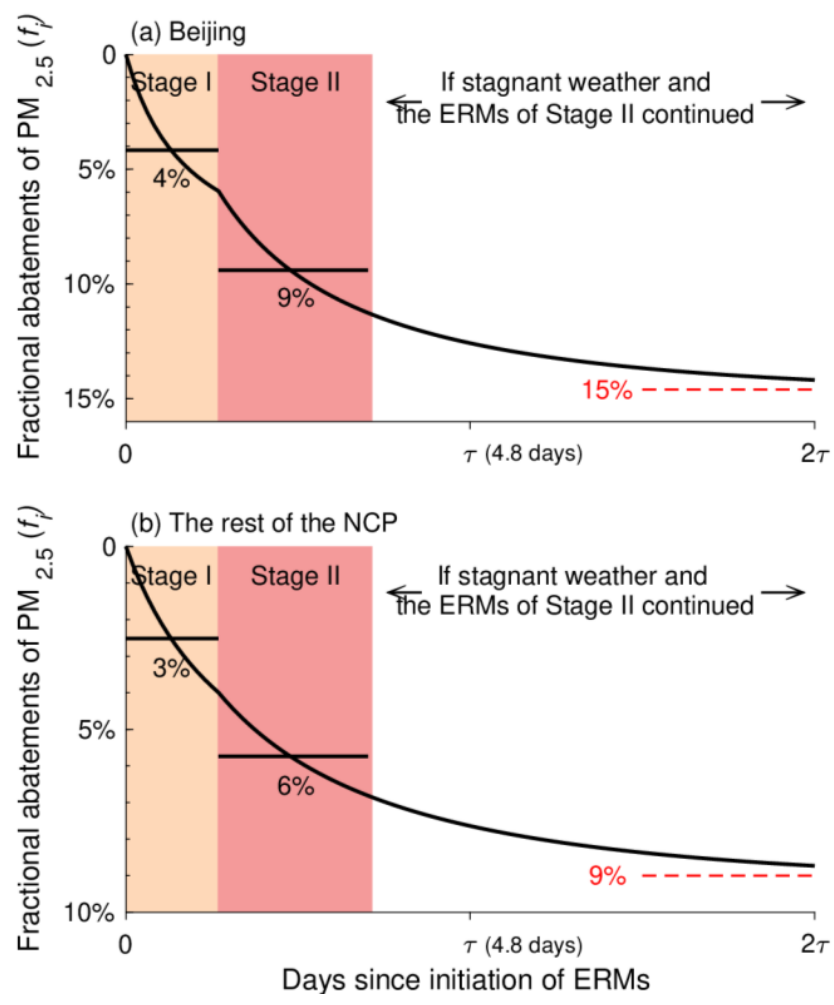

Fig. 8. Analytical solutions of the fractional abatements of $\mathrm{PM}_{2.5}\left(f_{i}\right.$, black curves) in (a) Beijing and (b) the rest of the NCP as a result of the ERMs implemented, as functions of days since the initiation of ERM enforcement (x-axis). The color blocks indicate the durations of Stages I (orange) and II (red), respectively. The mean analytical fractional abatements of $\mathrm{PM}_{2.5}$ during Stages I and II are indicated by the horizontal black lines. The maximum fractional abatements $\left(f_{\text {max }, i}\right)$ of PM 2.5 are indicated by the red dashed lines. 
By applying the values $\alpha_{j}$ (estimated by weighting the emission reductions in Table 2 , as described above) and $g_{i, j}$ (from Fig. 7), one can calculate the values of $f_{\text {max }, i}$. For Beijing, $f_{\text {max }, i}$ were $9 \%$ and $15 \%$ during Stages I and II, respectively. For the rest of the NCP, $f_{\max , i}$ were $8 \%$ and $9 \%$ during Stages I and II, respectively.

These results explained the ineffectiveness of the ERMs in alleviating surface $\mathrm{PM}_{2.5}$ pollution from December 6 to 10,2015 . If, hypothetically, the stagnant weather and the same ERM enforcement for Stage II had continued, then the fractional abatements of $\mathrm{PM}_{2.5}$ would have eventually approached $f_{\max , i}$ after approximately 10 days $(2 \tau)$. This is shown in Fig. 8 by the $f_{i}$ curves eventually approaching the $f_{\text {max }, i}$ values, which were $15 \%$ and $9 \%$ for Beijing and the rest of the NCP, respectively. In reality, however, the passage of a cold front ventilated the NCP boundary layer on December 10, 2015, and terminated the severe haze event. Thus, there was insufficient time for the $\mathrm{PM}_{2.5}$ concentrations to fully reflect the reduction in emissions, i.e., the fractional abatements of $\mathrm{PM}_{2.5}$ did not have enough time to reach their maximum potential values, $f_{\max , i}$.

\section{CONCLUSIONS}

Between December 6 and December 10 in 2015, the cities and provinces of the NCP, for the first time, executed ERMs to reduce anthropogenic emissions, with the goal of alleviating a severe $\mathrm{PM}_{2.5}$ episode. To evaluate the effectiveness of these measures, we first surveyed provincial/municipal documents and news reports to assess the emission reductions due to the ERMs in each of the NCP's five cities and provinces. Then, we simulated the $\mathrm{PM}_{2.5}$ concentrations in these areas during the clean period and with and without the reductions during the polluted period. The results indicated that the measures decreased the anthropogenic $\mathrm{PM}_{2.5}$ and its precursors, excepting $\mathrm{NH}_{3}$, across the NCP by $8-48 \%$. Our model simulations incorporating the reduced emission estimates were able to reproduce the observed $\mathrm{PM}_{2.5}$ concentrations and compositions throughout the event.

We found the effects of the ERMs on the $\mathrm{PM}_{2.5}$ concentrations to be surprisingly modest. During the episode, the overall mean decrease resulting from the measures was $7 \%$ in Beijing and $4 \%$ across the rest of the NCP; furthermore, local emissions accounted for only $18-22 \%$ of the surface $\mathrm{PM}_{2.5}$ in Beijing, whereas emissions originating elsewhere on the NCP and even farther away contributed $49-58 \%$ and 23-29\%, respectively. Excluding Beijing, 62\% of the mean surface concentration across the NCP was due to pollutants emitted locally, with the remainder (34-37\%) attributed to pollutants generated outside the NCP.

The ineffectiveness of the ERMs in mitigating the high $\mathrm{PM}_{2.5}$ concentrations can be explained by the increased lifetime of this pollutant ( 5 days) in the boundary layer of the NCP - a consequence of stagnant weather conditions that impeded horizontal and vertical ventilation - which, because of the ERMs' shorter duration, prevented the concentrations from fully reflecting the reduction in emissions. Thus, this episode stands in strong contrast to previous occasions, e.g., the Sino-African Summit, the Beijing Olympic Games, the
APEC summit, and the 2015 Chinese Military Parade, when temporary emission controls in BTH and its surrounding areas significantly improved the air quality in Beijing (e.g., Cheng et al., 2008; Wang et al., 2010; Liu et al., 2015; Zhang et al., 2016; Wang et al., 2017). However, the control measures were implemented for longer periods of time during those events. More importantly, the efficacy of the actions was aided by the effective ventilation of the boundary layer air in Beijing (e.g., Zhang et al., 2016).

Our results illustrate the challenge in reducing surface $\mathrm{PM}_{2.5}$ concentrations via ERMs during severe winter haze events, when the stagnant weather conditions impede the effectiveness of temporary measures. Anthropogenic emissions on the NCP under these circumstances must be reduced by a much larger percentage to substantially abate the $\mathrm{PM}_{2.5}$ concentrations, although these reductions would be economically costly. Concurrently issuing a stronger advisory for citizens to reduce outdoor activity and improve indoor air quality (e.g., by using air purifiers to filter $\mathrm{PM}_{2.5}$ ) is also necessary in order to reduce public exposure during these pollution episodes.

\section{ACKNOWLEDGMENT}

This work was supported by the Ministry of Science and Technology of China (2017YFC0209802) and by the National Natural Sciences Foundation of China (41975158). J. Guo was supported by the National Natural Sciences Foundation of China under Grant 41771399. Y. Zhang was supported by the National Natural Sciences Foundation of China under Grant 41675121.

\section{SUPPLEMENTARY MATERIAL}

Supplementary data associated with this article can be found in the online version at https://doi.org/10.4209/aaqr.2 019.09.0442

\section{REFERENCES}

Carter, W.P.L. (2000). Implementation of the SAPRC-99 chemical mechanism into the Models-3 framework. Report to the U.S. EPA. Statewide Air Pollution Research Center, University of California, Riverside, CA, USA.

Chen, R., Zhao, Z. and Kan, H. (2013). Heavy smog and hospital visits in Beijing, China. Am. J. Respir Crit. Care. Med. 188: 1170-1171. https://doi.org/10.1164/rccm.2013 04-0678LE

Chen, Z., Chen, D., Wen, W., Zhuang, Y., Kwan, M.P., Chen, B., Zhao, B., Yang, L., Gao, B., Li, R. and Xu, B. (2019). Evaluating the " $2+26$ " regional strategy for air quality improvement during two air pollution alerts in Beijing: variations in $\mathrm{PM}_{2.5}$ concentrations, source apportionment, and the relative contribution of local emission and regional transport. Atmos. Chem. Phys. 19: 6879-6891. https://doi.org/10.5194/acp-19-6879-2019

Cheng, Y.F., Heintzenberg, J., Wehner, B., Wu, Z.J., Su, H., $\mathrm{Hu}, \mathrm{M}$. and Mao, J.T. (2008). Traffic restrictions in Beijing during the Sino-African Summit 2006: Aerosol 
size distribution and visibility compared to long-term in situ observations. Atmos. Chem. Phys. 8: 7583-7594. https://doi.org/10.5194/acp-8-7583-2008

Cheng, Y.F., Zheng, G., Wei, C., Mu, Q., Zheng, B., Wang, Z., Gao, M., Zhang, Q., He, K., Carmichael, G., Pöschl, U. and $\mathrm{Su}, \mathrm{H}$. (2016). Reactive nitrogen chemistry in aerosol water as a source of sulfate during haze events in China. Sci. Adv. 2: e1601530. https://doi.org/10.1126/scia dv. 1601530

Dang, R. and Liao, H. (2019). Severe winter haze days in the Beijing-Tianjin-Hebei region from 1985 to 2017 and the roles of anthropogenic emissions and meteorology. Atmos. Chem. Phys. 19: 10801-10816. https://doi.org/10. 5194/acp-19-10801-2019

Emmons, L.K., Walters, S., Hess, P.G., Lamarque, J.F., Pfister, G.G., Fillmore, D., Granier, C., Guenther, A., Kinnison, D., Laepple, T., Orlando, J., Tie, X., Tyndall, G., Wiedinmyer, C., Baughcum, S.L. and Kloster, S. (2010). Description and evaluation of the Model for Ozone and Related chemical Tracers, version 4 (MOZART-4). Geosci. Model Dev. 3: 43-67. https://doi.org/10.5194/gmd-3-43-2010

Fang, C., Zhang, Z., Jin, M., Zou, P. and Wang, J. (2017). Pollution characteristics of $\mathrm{PM}_{2.5}$ aerosol during haze periods in Changchun, China. Aerosol Air Qual. Res. 17: 888-895. https://doi.org/10.4209/aaqr.2016.09.0407

Fu, T.M., Jacob, D.J. and Heald, C.L. (2009). Aqueousphase reactive uptake of dicarbonyls as a source of organic aerosol over eastern North America. Atmos. Environ. 43: 1814-1822. https://doi.org/10.1016/j.atmos env.2008.12.029

Fu, T.M., Jacob, D.J., Wittrock, F., Burrows, J.P., Vrekoussis, M. and Henze, D.K. (2008). Global budgets of atmospheric glyoxal and methylglyoxal, and implications for formation of secondary organic aerosols. J. Geophys. Res. 113: D15303. https://doi.org/10.1029/2007JD009505

Gao, J., Peng, X., Chen, G., Xu, J., Shi, G.L., Zhang, Y.C. and Feng, Y.C. (2016). Insights into the chemical characterization and sources of $\mathrm{PM}_{2.5}$ in Beijing at a 1-h time resolution. Sci. Total. Environ. 542: 162-171. https://doi.org/10.1016/j.scitotenv.2015.10.082

Georgiou, G.K., Christoudias, T., Proestos, Y., Kushta, J., Hadjinicolaou, P. and Lelieveld, J. (2018). Air quality modelling in the summer over the Eastern Mediterranean using WRF/Chem: Chemistry and aerosol mechanisms intercomparison. Atmos. Chem. Phys. 18: 1555-1571. https://doi.org/10.5194/acp-18-1555-2018

Gilliam, R.C., Godowitch, J.M. and Rao, S.T. (2012). Improving the horizontal transport in the lower troposphere with four dimensional data assimilation. Atmos. Environ. 53: 186-201. https://doi.org/10.1016/j.atmosenv.2011.10. 064

Ginoux, P., Chin, M., Tegen, I., Prospero, J.M., Holben, B., Dubovik, O. and Lin, S.J. (2001). Sources and distribution of dust aerosols simulated with the GOCART model. $J$. Geophys. Res. 106: 20255-20274. https://doi.org/10.102 9/2000JD000053

Grell, G.A., Peckham, S.E., Schmitz, R., Mckeen, S.A., Frost, G., Skamarock, W.C. and Eder, B. (2005). Fully coupled "online" chemistry within the WRF model.
Atmos. Environ. 39: 6957-6975. https://doi.org/10.1016/ j.atmosenv.2005.04.027

Guenther, A., Karl, T., Harley, P., Wiedinmyer, C., Palmer, P.I. and Geron, C. (2006). Estimates of global terrestrial isoprene emissions using MEGAN (model of emissions of gases and aerosols from nature). Atmos. Chem. Phys. 6: 3181-3210. https://doi.org/10.5194/acp-6-3181-2006

Guo, J., He, J., Liu, H., Miao, Y., Liu, H. and Zhai, P. (2016a). Impact of various emission control schemes on air quality using WRF-Chem during APEC China 2014. Atmos. Environ. 140: 311-319. https://doi.org/10.1016/ j.atmosenv.2016.05.046

Guo, J., Miao, Y., Zhang, Y., Liu, H., Li, Z., Zhang, W., He, J., Lou, M., Yan, Y., Bian, L. and Zhai, P. (2016b). The climatology of planetary boundary layer height in China derived from radiosonde and reanalysis data. Atmos. Chem. Phys. 16: 13309-13319. https://doi.org/10.5194/a cp-16-13309-2016

Guth, J., Marécal, V., Josse, B., Arteta, J. and Hamer, P. (2018). Primary aerosol and secondary inorganic aerosol budget over the Mediterranean Basin during 2012 and 2013. Atmos. Chem. Phys. 18: 4911-4934. https://doi.org/ 10.5194/acp-18-4911-2018

Han, X. and Zhang, M.G. (2019). Assessment of the regional source contributions to $\mathrm{PM}_{2.5}$ mass concentration in Beijing. Atmos. Oceanic Sci. Lett. 11: 143-149. https://doi.org/10.1080/16742834.2018.1412796

He, H., Wang, Y., Ma, Q., Ma, J., Chu, B., Ji, D., Tang, G., Liu, C., Zhang, H. and Hao, J. (2014). Mineral dust and $\mathrm{NO}_{\mathrm{x}}$ promote the conversion of $\mathrm{SO}_{2}$ to sulfate in heavy pollution days. Sci. Rep. 4: 4172. https://doi.org/10.1038/srep04172

Huang, K., Zhang, X. and Lin, Y. (2015). The "APEC Blue" phenomenon: Regional emission control effects observed from space. Atmos. Res. 164-165: 65-75. https://doi.org/ 10.1016/j.atmosres.2015.04.018

Huang, R.J., Zhang, Y., Bozzetti, C., Ho, K.F., Cao, J.J., Han, Y., Daellenbach, K.R., Slowik, J.G., Platt, S.M., Canonaco, F., Zotter, P., Wolf, R., Pieber, S.M., Bruns, E.A., Crippa, M., Ciarelli, G., Piazzalunga, A., Schwikowski, M., Abbaszade, G., ... Prévót, A.S.H. (2014). High secondary aerosol contribution to particulate pollution during haze events in China. Nature 514: 218222. https://doi.org/10.1038/nature13774

Huang, W., Fang, D., Shang, J., Li, Z., Zhang, Y., Huo, P., Liu, Z., Schauer, J.J. and Zhang, Y. (2018). Relative impact of short-term emissions controls on gas and particle-phase oxidative potential during the 2015 China Victory Day Parade in Beijing, China. Atmos. Environ. 183: 49-56. https://doi.org/10.1016/j.atmosenv.2018.03.046

Huang, W., Saathoff, H., Shen, X., Ramisetty, R., Leisner, T. and Mohr, C. (2019). Seasonal characteristics of organic aerosol chemical composition and volatuluty in Stuttgart, Germany. Atmos. Chem. Phys. 19: 11687-11700. https://doi.org/10.5194/acp-19-11687-2019

Hung, H.M., Hsu, M.N. and Hoffmann, M.R. (2018). Quantification of $\mathrm{SO}_{2}$ oxidation on interfacial surfaces of acidic micro-droplets: Implication for ambient sulfate formation. Environ. Sci. Technol. 52: 9079-9086. https://doi.org/10.1021/acs.est.8b01391 
Jacob, D.J. (1999). Introduction to atmospheric chemistry, Princeton University Press, Princeton, New Jersey, pp. 266.

Jeong, J.I. and Park, R.J. (2013). Effects of the meteorological variability on regional air quality in East Asia. Atmos. Environ. 69: 46-55. https://doi.org/10.1016/ j.atmosenv.2012.11.061

Kalnay, E., Kanamitsu, M., Kister, R., Collins, W., Deaven, D., Gandin, L., Iredell, M., Saha, S., White, G., Woollen, J., Zhu, Y., Chelliah, M., Ebisuzaki, W., Higgins, W., Janowiak, J., Mo, K.C., Ropelewski, C., Wang, J., Leetmaa, A., ... Joseph, D. (1996). The NCEP/NCAR 40year reanalysis project. Bull. Am. Meteorol. Soc. 77: 437471. https://doi.org/10.1175/1520-0477(1996)077<0437: TNYRP> 2.0.CO;2

Lane, T.E., Donahue, N.M. and Pandis, S.N. (2008). Simulating secondary organic aerosol formation using the volatility basis-set approach in a chemical transport model. Atmos. Environ. 42: 7439-7451. https://doi.org/10. 1016/j.atmosenv.2008.06.026

LeGrand, S.L., Polashenski, C., Letcher, T.W., Creighton, G.A., Peckham, S.E. and Cetola, J.D. (2019). The AFWA dust emission scheme for the GOCART aerosol model in WRF-Chem v3.8.1. Geosci. Model Dev. 12: 131-166. https://doi.org/10.5194/gmd-12-131-2019

Lei, Y., Zhang, Q., He, K.B. and Streets, D.G. (2011). Primary anthropogenic aerosol emission trends for China, 1990-2005. Atmos. Chem. Phys. 11: 931-954. https://doi. org/10.5194/acp-11-931-2011

Leung, D.M., Tai, A.P.K., Mickley, L.J., Moch, J.M., van Donkelaar, A., Shen, L. and Martin, R.V. (2018). Synoptic meteorological modes of variability for fine particulate matter $\left(\mathrm{PM}_{2.5}\right)$ air quality in major metropolitan regions of China. Atmos. Chem. Phys. 18: 6733-6748. https://doi. org/10.5194/acp-18-6733-2018

Li, J., Xie, S.D., Zeng, L.M., Li, L.Y., Li, Y.Q. and Wu, R.R. (2015). Characterization of ambient volatile organic compounds and their sources in Beijing, before, during, and after Asia-Pacific Economic Cooperation China 2014. Atmos. Chem. Phys. 15: 7945-7959. https://doi.org/ 10.5194/acp-15-7945-2015

Li, M., Zhang, Q., Kurokawa, J.I., Woo, J.H., He, K., Lu, Z., Ohara, T., Song, Y., Streets, D.G., Carmichael, G.R., Cheng, Y., Hong, C., Huo, H., Jiang, X., Kang, S., Liu, F., Su, H. and Zheng, B. (2017). MIX: a mosaic Asian anthropogenic emission inventory under the international collaboration framework of the MICS-Asia and HTAP. Atmos. Chem. Phys. 17: 935-963. https://doi.org/10.5194 /acp-17-935-2017

Li, N., Fu, T.M., Cao, J., Lee, S., Huang, X.F., He, L.Y., Ho, K.F., Fu, J.S. and Lam, Y.F. (2013). Sources of secondary organic aerosols in the Pearl River Delta region in fall: Contributions from the aqueous reactive uptake of dicarbonyls. Atmos. Environ. 76: 200-207. https://doi.org/ 10.1016/j.atmosenv.2012.12.005

Liu, H., He, J., Guo, J., Miao, Y., Yin, J., Wang, Y., Xu, H., Liu, H., Yan, Y., Li, Y. and Zhai, P. (2017). The blue skies in Beijing during APEC 2014: A quantitative assessment of emission control efficiency and meteorological influence. Atmos. Environ. 167: 235-244. https://doi.org/ 10.1016/j.atmosenv.2017.08.032

Liu, J., Xie, P., Wang, Y., Wang, Z., He, H. and Liu, W. (2015). Haze observation and control measure evaluation in Jing-Jin-Ji (Beijing, Tianjin, Hebei) area during the period of the Asia-Pacific Economic Cooperation (APEC) meeting. Bull. Chin. Acad. Sci. 30: 368-377. https://doi.org /10.16418/j.issn.1000-3045.2015.03.011

Liu, M., Song, Y., Zhou, T., Xu, Z., Yan, C., Zheng, M., Wu, Z., Hu, M., Wu, Y. and Zhu, T. (2017). Fine particle pH during severe haze episodes in northern China. Geophys. Res. Lett. 44: 5213-5221. https://doi.org/10.1002/2017G L073210

Liu, P., Ye, C., Xue, C., Zhang, C., Mu, Y. and Sun, X. (2020). Formation mechanisms of atmospheric nitrate and sulfate during the winter haze pollution periods in Beijing: Gas-phase, heterogeneous and aqueous-phase chemistry. Atmos. Chem. Phys. 20: 4153-4165. https://doi.org/10.51 94/acp-20-4153-2020

Liu, T., Gong, S., He, J., Yu, M., Wang, Q., Li, H., Liu, W., Zhang, J., Li, L., Wang, X., Li, S., Lu, Y., Du, H., Wang, Y., Zhou, C., Liu, H. and Zhao, Q. (2017). Attributions of meteorological and emission factors to the 2015 winter severe haze pollution episodes in China's Jing-Jin-Ji area. Atmos. Chem. Phys. 17: 2971-2980. https://doi.org/10.51 94/acp-17-2971-2017

Lu, Z., Zhang, Q. and Streets, D.G. (2011). Sulfur dioxide and primary carbonaceous aerosol emissions in China and India. 1996-2010. Atmos. Chem. Phys. 11: 9839-9864. https://doi.org/10.5194/acp-11-9839-2011

Ministry of Ecology and Environment of the People's Republic of China (2018). Report on the State of the Ecology and Environment in China 2017.

Ministry of Ecology and Environment of the People's Republic of China (2019). Report on the State of the Ecology and Environment in China 2018.

Ministry of Environmental Protection of the People's Republic of China (2012). Ambient Air Quality Standards (GB3095-2012).

Ministry of Environmental Protection of the People's Republic of China (2013). Monitoring and Warning Scheme for Heavy Pollution Weather in Beijing, Tianjin, Hebei, and Its Surrounding Areas (HF [2013] No. 111).

Ministry of Environmental Protection of the People's Republic of China (2014). Report on the State of the Environment in China 2013.

Ministry of Environmental Protection of the People's Republic of China (2015). Report on the State of the Environment in China 2014.

Ministry of Environmental Protection of the People's Republic of China (2016). Report on the State of the Environment in China 2015.

Ministry of Environmental Protection of the People's Republic of China (2017). Report on the State of the Environment in China 2016.

Schleicher, N., Norra, S., Chen, Y., Chai, F. and Wang, S. (2012). Efficiency of mitigation measures to reduce particulate air pollution - A case study during the Olympic Summer Games 2008 in Beijing, China. Sci. 
Total Environ. 427-428: 146-158. https://doi.org/10.101 6/j.scitotenv.2012.04.004

Seinfeld, J.H. and Pandis, S.N. (2006). Atmospheric chemistry and physics: From air pollution to climate change (II), John Wiley \& Sons, Inc., Hoboken, New Jersey, pp. 963.

Shao, J., Chen, Q., Wang, Y., Lu, X., He, P., Sun, Y., Shah, V., Martin, R.V., Philip, S., Song, S., Zhao, Y., Xie, Z., Zhang, L. and Alexander, B. (2019). Heterogeneous sulfate aerosol formation mechanisms during wintertime Chinese haze events: Air quality model assessment using observations of sulfate oxygen isotopes in Beijing. Atmos. Chem. Phys. 19: 6107-6123. https://doi.org/10.5194/acp19-6107-2019

State Council of the People's Republic of China (2013). Air Pollution Prevention and Control Action Plan (GF [2013] No. 37).

Tang, R., Wu, Z., Li, X., Wang, Y., Shang, D., Xiao, Y., Li, M., Zeng, L., Wu, Z., Hallquist, M., Hu, M. and Guo, S. (2018). Primary and secondary organic aerosols in summer 2016 in Beijing. Atmos. Chem. Phys. 18: 40554068. https://doi.org/10.5194/acp-18-4055-2018

Tie, X., Huang, R.J., Cao, J., Zhang, Q., Cheng, Y., Su, H., Chang, D., Pöschl, U., Hoffmann, T., Dusek, U., Li, G., Worsnop, D.R. and O'Dowd, C. (2017). Severe pollution in China amplified by atmospheric moisture. Sci. Rep. 7: 15760. https://doi.org/10.1038/s41598-017-15909-1

Wang, F., Chen, D.S., Cheng, S.Y., Li, J.B., Li, M.J. and Ren, Z.H. (2010). Identification of regional atmospheric $\mathrm{PM}_{10}$ transport pathways using HYSPLIT, MM5-CMAQ and synoptic pressure pattern analysis. Environ. Modell. Software 25: 927-934. https://doi.org/10.1016/j.envsoft. 2010.02.004

Wang, G., Zhang, R., Gomez, M.E., Yang, L., Levy Zamora, M., Hu, M., Lin, Y., Peng, J., Guo, S., Meng, J., Li, J., Cheng, C., Hu, T., Ren, Y., Wang, Y., Gao, J., Cao, J., An, Z., Zhou, W., ... Molina, M.J. (2016). Persistent sulfate formation from London fog to Chinese haze. Proc. Natl. Acad. Sci. U.S.A. 113: 13630-13635. https://doi.org/ 10.1073/pnas.1616540113

Wang, G., Cheng, S., Wei, W., Yang, X., Wang, X., Jia, J., Lang, J. and Lv, Z. (2017). Characteristics and emissionreduction measures evaluation of $\mathrm{PM}_{2.5}$ during the two major events: APEC and Parade. Sci. Total Environ. 595: 81-92. https://doi.org/10.1016/j.scitotenv.2017.03.231

Wang, H., Li, J., Peng, Y., Zhang, M., Che, H. and Zhang, X. (2019). The impacts of the meteorology features on $\mathrm{PM}_{2.5}$ levels during a severe haze episode in central-east China. Atmos. Environ. 197: 177-189. https://doi.org/10. 1016/j.atmosenv.2018.10.001

Wang, J., Zhang, M., Bai, X., Tan, H., Li, S., Liu, J., Zhang, R., Wolters, M.A., Qin, X., Zhang, M., Lin, H., Li, Y., Li, J. and Chen, L. (2017). Large-scale transport of $\mathrm{PM}_{2.5}$ in the lower troposphere during winter cold surges in China. Sci. Rep. 7: 13238. https://doi.org/10.1038/s41598-01713217-2

Wang, S., Zhao, M., Wu, Y., Zhou, Y., Lei, Y., He, K., Fu, L. and Hao, J. (2010). Quantifying the air pollutants emission reduction during the 2008 Olympic Games in
Beijing. Environ. Sci. Technol. 44: 2490-2496. https://doi.org/10.1021/es9028167

Wang, X., Jiang, F., Xu, S., Tian, X. and Yao, D. (2020). Assessment of emergency emission reduction effect during a severe air pollution episode in Yangtze River Delta region. Res. Environ. Sci. 33: 783-791. (in Chinese) https://doi.org/10.13198/j.issn.1001-6929.2019.12.12

Wang, Y., McElroy, M.B., Boersma, K.F., Eskes, H.J. and Veefkind, J.P. (2007). Traffic restrictions associated with the Sino-African summit: Reductions of $\mathrm{NO}_{\mathrm{x}}$ detected from space. Geophys. Res. Lett. 34: 402-420. https://doi.org/10.1029/2007GL029326

Wiedinmyer, C., Akagi, S.K., Yokelson, R.J., Emmons, L.K., Al-Saadi, J.A., Orlando, J.J. and Soja, A.J. (2011). The Fire Inventory from NCAR (FINN): A high resolution global model to estimate the emissions from open burning. Geosci. Model Dev. 4: 625-641. https://doi.org/ 10.5194/gmd-4-625-2011

Wu, W.J., Chang, X., Xing, J., Wang, S.X. and Hao, J.M. (2017). Assessment of $\mathrm{PM}_{2.5}$ pollution mitigation due to emission reduction from main emission sources in the Bejing-Tianjin-Hebei region. Environ. Sci. 38: 867-875. (in Chinese) https://doi.org/10.13227/j.hjkx.201607191

Zaveri, R.A., Easter, R.C., Fast, J.D. and Peters, L.K. (2008). Model for Simulating Aerosol Interactions and Chemistry (MOSAIC). J. Geophys. Res. 113: D13204. https://doi.org/10.1029/2007JD008782

Zhang, H., Yu, C., Su, L., Wang, Y. and Chen, L. (2017). Analysis on effectiveness of $\mathrm{SO}_{2}$ and $\mathrm{NO}_{2}$ emission reduction in North China Plain by OMI data during the Military Parade 2015. Remote Sens. Technol. Appl. 32: 734-742. http://www.rsta.ac.cn/EN/Y2017/V32/I4/734

Zhang, H., Yuan, H., Liu, X., Yu, J. and Jiao, Y. (2018). Impact of synoptic weather patterns on $24 \mathrm{~h}$-average $\mathrm{PM}_{2.5}$ concentrations in the North China Plain during 2013-2017. Sci. Total Environ. 627: 200-210. https://doi.org/10.1016/j.scitotenv.2018.01.248

Zhang, J., Xue, H., Deng, Z., Ma, N., Zhao, C. and Zhang, Q. (2014). A comparison of the parameterization schemes of fog visibility using the in-situ measurements in the North China Plain. Atmos. Environ. 92: 44-50. https://doi.org/10.1016/j.atmosenv.2014.03.068

Zhang, L., Liu, L.C., Zhao, Y.H., Gong, S.L., Zhang, X.Y., Henze, D.K., Capps, S., Fu, T.M. and Zhang, Q. (2015). Source attribution of particulate matter pollution over North China with the adjoint method. Environ. Res. Lett. 10: 084011. https://doi.org/10.1088/1748-9326/10/8/084011

Zhang, L., Shao, J., Lu, X., Zhao, Y., Hu, Y., Henze, D.K., Liao, H., Gong, S. and Zhang, Q. (2016). Sources and processes affecting fine particulate matter pollution over North China: An adjoint analysis of the Beijing APEC period. Environ. Sci. Technol. 50: 8731-8740. https://doi.org/10.1021/acs.est.6b03010

Zhang, Q., Streets, D.G., Carmichael, G.R., He, K.B., Huo, H., Kannari, A., Klimont, Z., Park, I.S., Reddy, S., Fu, J.S., Chen, D., Duan, L., Lei, Y., Wang, L.T. and Yao, Z.L. (2009). Asian emissions in 2006 for the NASA INTEX-B mission. Atmos. Chem. Phys. 9: 5131-5153. https://doi.org/10.5194/acp-9-5131-2009 
Zhang, Q., Ma, Q., Zhao, B., Liu, X., Wang, Y., Jia, B. and Zhang, X. (2018). Winter haze over North China Plain from 2009 to 2016: Influence of emission and meteorology. Environ. Pollut. 242: 1308-1318. https://doi.org/10.1016 /j.envpol.2018.08.019

Zhang, R., Li, Q. and Zhang, R. (2014). Meteorological conditions for the persistent severe fog and haze event over eastern China in January 2013. Sci. China Earth Sci. 57: 26-35. https://doi.org/10.1007/s11430-013-4774-3

Zhao, Y., Liu, Y., Ma, J., Ma, Q. and He, H. (2017).
Heterogeneous reaction of $\mathrm{SO}_{2}$ with soot: The roles of relative humidity and surface composition of soot in surface sulfate formation. Atmos. Environ. 152: 465-476. https://doi.org/10.1016/j.atmosenv.2017.01.005

Received for review, September 9, 2019

Revised, April 26, 2020

Accepted, April 28, 2020 